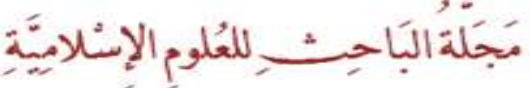

Researcher Journal For Islamic Sciences

Published by the College of Islamic Sciences at the University of Fallujah

ISSN p.p:2708-3993 / ISSN o.l: 2708-4000

Vol;3- Issue;1/ (2020-2021)

\title{
Provisions Of Friday، Eid And Funerals Prayers For Expatriates
}

\section{A . M. Dr. Dahir Faisal Badawi/ University of Anbar / Center for}

Strategic Studies/Dhair.faysal@uoanbar.iq/07801115901

Abstract: Allah Almighty has made the law of Islam valid for every time and place and seeks to ensure the best life for human beings. Human life with naturally accept developing and change، so the provisions of the Sharia with their flexibility to keep up with this change. Muslim is commanded to perform the rituals of Allah Almighty. He may move from one place to another and from a Muslim country to a non-Muslim country، so he desires to practice the rituals of his religion that Allah has distinguished him with. For the reason that the expatriate Muslim does not differ in its rulings from the non-immigrant Muslim who resides in his country in that it is obligatory to display the rituals of religion outwardly so long as it is not hidden from himself، his money، his honor and his religion.

Keywords: (Provisions. Friday. prayers. funerals. expatriates)

rV

Doi:10.37940/RJIS. 2021.2.1.2 


\title{
أحكام صلاة الجمعة والعيدين والجنائز للمغتربين
}

\author{
ا. م. د ظاهر فيصل بديوي/ جامعه الانبار / مركز الدراسات الاستراتيجية
} •v^.11109.1/Dhair.faysal@uoanbar.iq

الملخص:

جعل الله عز وجل شريعة الإسلام صالحة لكل زمان ومكان وتسعى لضمان أفضل حياة لبني الإنسان على وجه هذه البسيطة

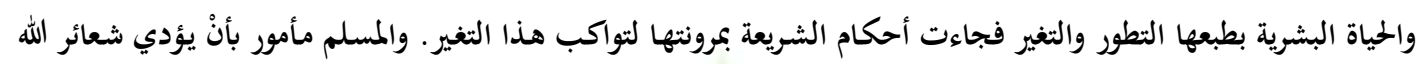
تعالى وقد ينتقل من مكان إلى آخر ومن دولة مسلمة إلى غير مسلمة فهو يرغب في ممارسة شعائر دينه التي ميزه الله بها ومن هذه بـاء

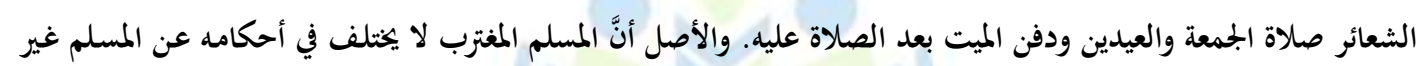

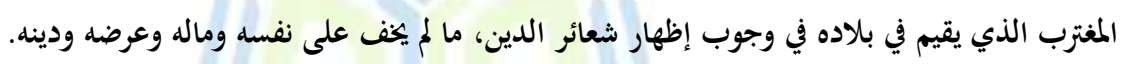
الكلمات المفتاحية: (صلاة، الجممعة، العيدين، الجنائز، مغتربين).

广人

Doi:10.37940/RJIS. 2021.2.1.2 


\section{أحكام صلاة الجمعة والعيدين والجنائز للمغتربين

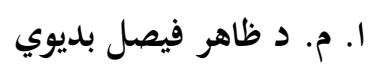 \\ جامعه الانبار مركز الدراسات الاستراتيجية}

المقدمة

الحمد لله رب العالمين والصلاة والسلام على أشرف العالمين المبعوث رممة للخلائق أجمعين وعلى آله وصحبه ومن

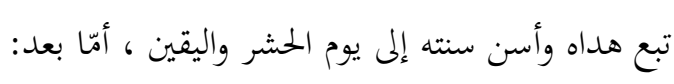

فهذا بحث متواضع في أبرز المسائل التي تخص المسلمين المغتربين في صلاة الجمعة والعيدين والجنائز الميته (صلاة

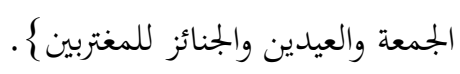

فحينما يقيم المسلم المغترب في مكان اغترابه فإنأَه يرغب في ممارسة شعائر دينة التي ميّه الله بما وتفضل عليه بشرعها ـ ومنها صلاة الجمعة وصلاة العيدين ودفن الجثمان بعد الصلاة عليه.

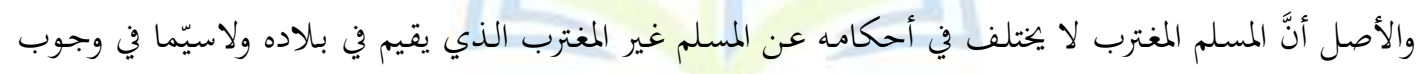

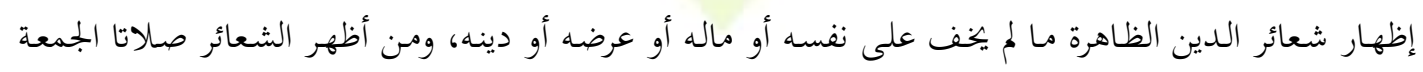
والعيدين.

ولذلك قد وجدت بضع مسائل في هذه الشعائر الظاهرة يحتاج إليها المسلم المغترب في غربته ، رغبت في بثثها

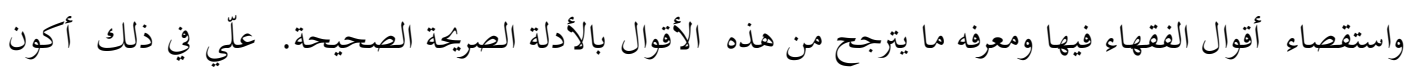

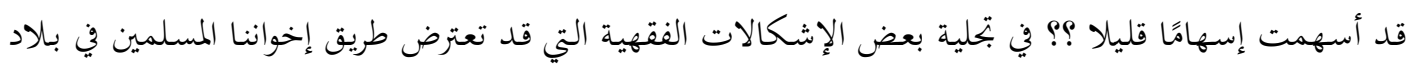
الغربة .

rq

Doi:10.37940/RJIS. 2021.2.1.2 


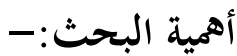

تأتي أهمية البحث في أنّه يتناول أهم شعائر الدين الواجب إظهارها وهي صلاة الجمعة والعيدين وكيف للمسلم

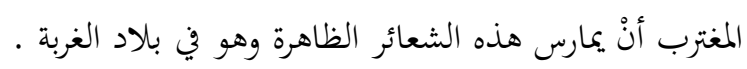

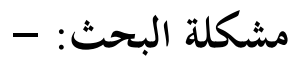

تتلخص مشكلة البحث في المسلم المغترب فهو مأمور بأداء شعائر الإسلام الظاهرة والتي منها صلاة الجمعة والعيدين وهو في بلد غير المسلمين وقد يكون في بلد يمنع فيه أداء شعائر غير ذلك البلد.

$$
\text { حدود البحث :- }
$$

اقتصر هذا البحث على حكم صلاة الجمعة والعيدين والجنائز للمسلم المغترب واستفتاء أقوال الفقهاء فيها.

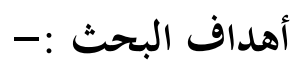

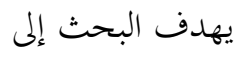

1:- بيان حكم صلاة الجمعة للمغتربين

r:- بيان حكم صلاة العيدين للمغتربين

r:- بيان احكام الجنائز للمغتربين

أمّا خطة البحث فقد اقتضى تقسيمها على مقدمة ومباحث ثلاثة وخاتمة .

أمّا المقدمة فقد بينت فيها سبب اختيار الموضوع ، وأمّا عن المباحث فقد اشتمل المبحث الأول على صلاة الجمعة للمغتربين والمبحث الثاني تضمن صلاة العيدين ، وجاء المبحث الثالث مبيناً فيه حكم دفن المسلم المغترب في مقابر

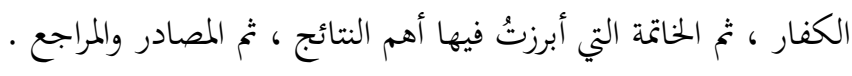

r. 


\section{المبحث الأول: حكم صلاة الجمعة للمغتربين}

المطلب الأول: إذن الإمام في إقامة الجمعة

اختلف الفقهاء في اشتراط إذن الإمام في إقامة الجمعة على ثلاثة أقوال : القول الأول : أنّ لا يشترط لصحتها إذن الإمام ، وهذا قول المالكية(1) ، والشافعية(r) ، واصح الروايتين عند الامام (r)

القول الثاني : أنه يشترط لصحتها إذن الإمام، وهذا قول الحنفية() ، ورواية عنـد الحنابلة(ه). القول الثالث : أنّ إذن الإمام يشترط لوجوبها لا لصحتها، وهذا رواية عند الحنابلة(؟). الأدلة : - 20 - n

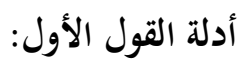

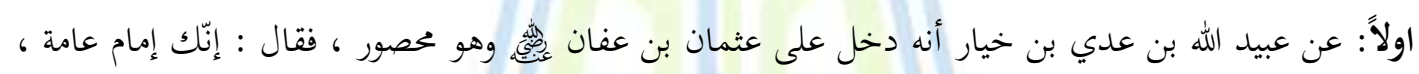

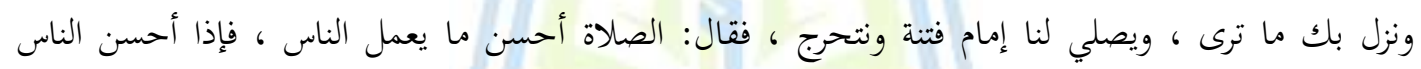

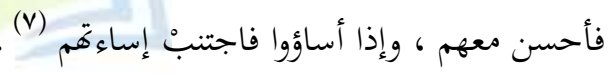

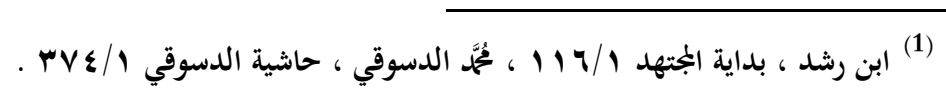

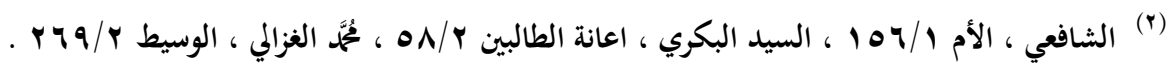

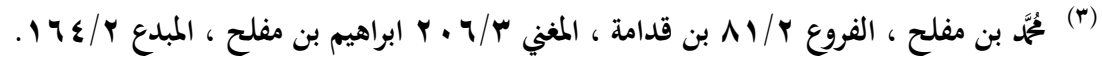

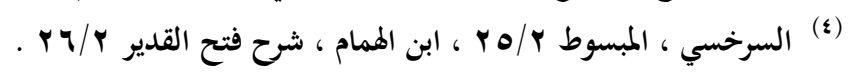

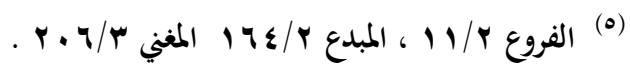

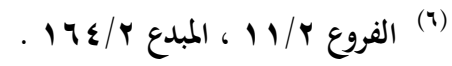

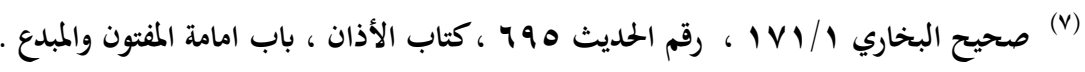
r) 


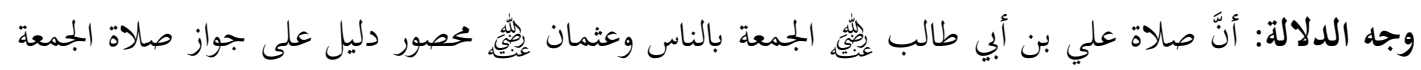

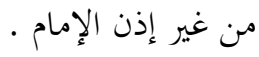

ثانيا : أنَّ صلاة الجمعة من فرائض الأعيان فلم يشترط لما إذن الإمام كالظهر (1).

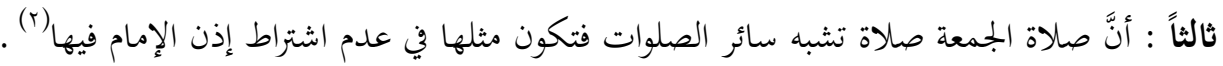
دليل القول الثاني : أنه لا يقيم صلاة الجمعة إلّا الأئمة في كل عصر فصار ذلك إجماعًا على عدم جواز إقامتها من غير إذن من الإمام (r) أمّا القول الثالث فلم أجد له أدلّة خاصة به .

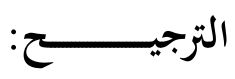

بعد النظر في هذه المسألة ومعرفة الأقوال الواردة فيها والاطلاع على أدلتها ومناقشة ما يحتاج إلى مناقشة منها تبين لي - والله أعلم بالصواب -أنَّ القول الراجح هو القول الأول وهو أنَّهَ لا يشترط إذن الإمام في صحة إقامة صلاة الجمعة ـ. وذلك لقوة أدلته وسلامتها من المناقشة ولضعف دليل القول الثاني وعدم سلامته من المناقشة ـ ولتعذر إمكانه ولاسيّما على أوليك المغتربين من المسلمين الذين يقيمون في بلاد الكفار، فلا يككنهم الحصول على إذن من سئل إمام البلد الذي يقيمون فيه ، ولو استطاعوا الحصول على إذنه فإنّه يستطيع منعهم إقامتها برجوعه عن إذنه فيها في

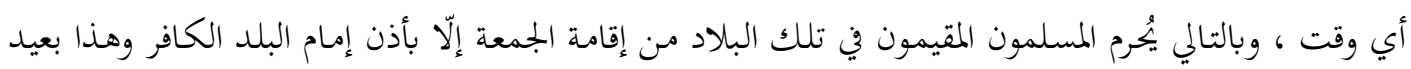

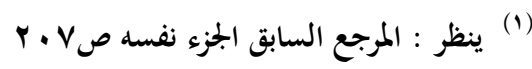

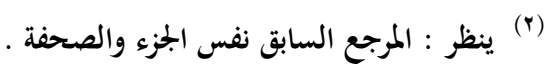

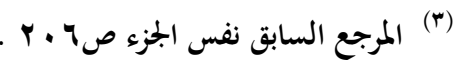

rt 
لأنَّ فيه سبيلًا للكافرين على المسلمين ، و الله لم يجعل للكافرين على المؤمنين سبيلاً ، قال تعالى $\{$ ولن يجعل الله

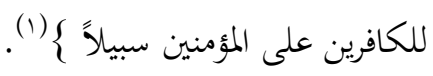

المطلب الثاني: العدد الذي تقام فيه الجمعة

قد يوجد بعض المسلمين في بلد من بلاد الكفار ويرغبون في إقامة صلاة الجمعة ولكنهم عدد قليل ، فهل يصح

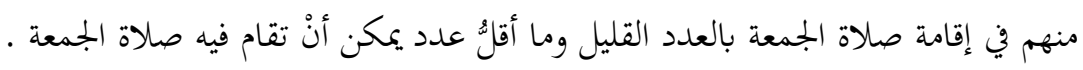

اختلف أهل العلم في العدد الذي تقام فيه الجمعة على أقوال كثيرة ، أهمها :

القول الأول : أغّّا تنعقد بثلاثة رجال ، وهذا القول رواية عند الحنابلة(r)، وقول أبي يوسف من الحنفية(r)، واختيار

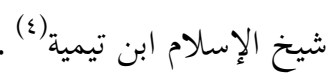

القول الثاني : أغّا تنعقد بأربعين رجلاً ، وهذا مذهب الشافعية(ه)، والرواية المشهورة عند الحنابلة(؟) . القول الثالث : أثّا تنعقد بخمسين رجلاً، وهذا رواية عند الحنابلة(V). القول الرابع : لاتنعقد الجمعة الا بعدد يمكن ان تتقرى بهم قرية(^) .

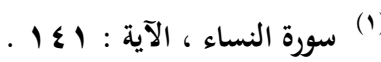

$$
\begin{aligned}
& \text { ا }
\end{aligned}
$$

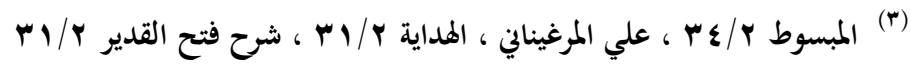

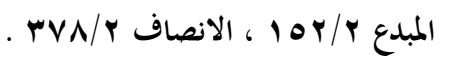

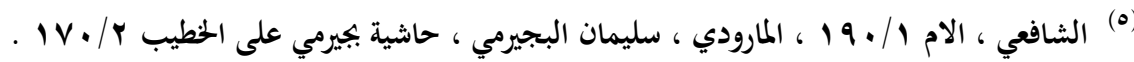

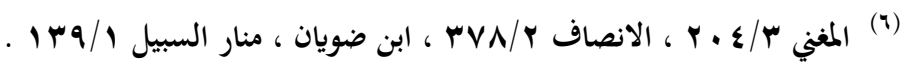

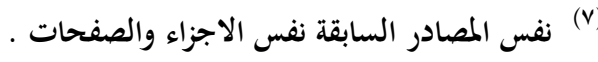

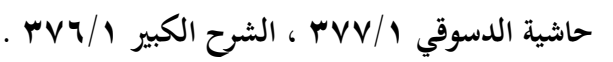

rT

Doi:10.37940/RJIS. 2021.2.1.2 


\section{القول الخامس : أهّا تنعقد بأربعة ، وهذا مذهب الحنفية(') ورواية عند الحنابلة(r).}

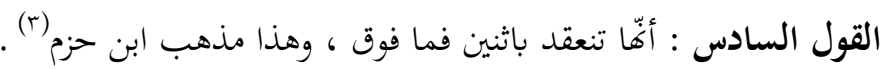

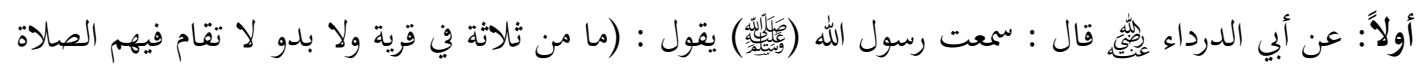
إلّا قد استحوذ عليهم الشيطان فعليك بالجماعة ، فإنما يأكل الذئب من الغنم القاصية)(؛ (؛). وجه الدلالة : أنَّ الصلاة في هذا الحديث عامة تشمل الجمعة وغيرها ، فإذا كانوا ثلاثة في قرية لا تقام فيهم الصلاة ومنها الجمعة فإنَّ الشيطان قد استحوذ عليهم . وهذا يدل على وجوب صلاة الجمعة على الثلاثة ، ولا يمكن أنْ

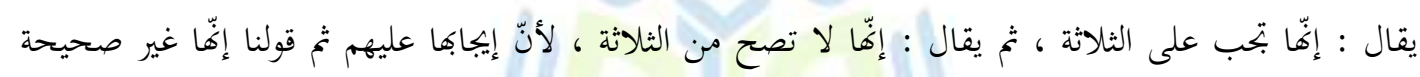
تضاد معناه : أمرناهم بشيء باطل والأمر بالشيء الباطل حرام . ثانياً : قال الله تعالى : \} يا ايها الذين أمنوا اذا نودي للصلاة من يوم الجمعة فاسعوا الى كر الله وذروا البيع ... الآية) (0)

وجه الدلالة: أنَّ هذه الصيغة الواردة في الآية صيغة الجمع فيدخل فيها الثلاثة ، فيكون الثلاثة مأمورين بالسعي إلى صلاة الجمعة وهذا يدل على أهّا تنعقد بكم (1).

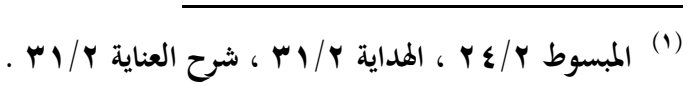

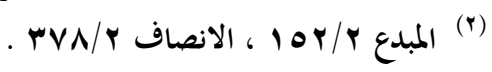

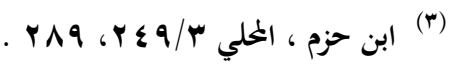

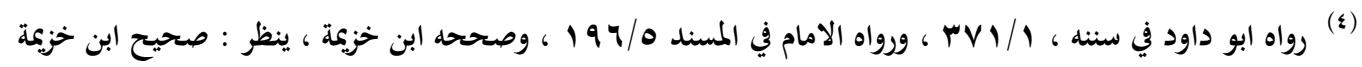

rร

Doi:10.37940/RJIS. 2021.2.1.2 
ثالثاً : أن هذا العدد أقلُ الجمع فهو يتناوله اسم الجمع فتنعقد به الجماعة كالأربعين(r) . رابعاً: أن المثنى في حكم الجماعة حتى يتقدم الإمام عليهما ، ويف الجماعة معنى الاجتماع ، وذلك يتحقق بالمثنى (r). أدلة القول الثاني :

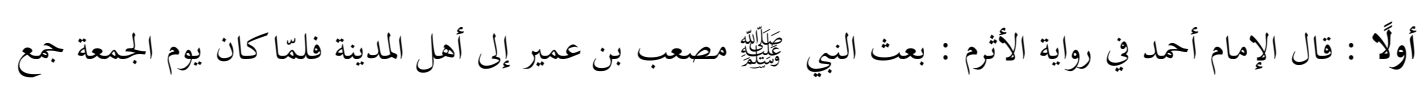

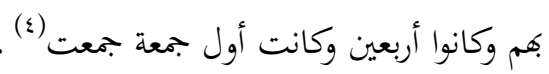
وجه الدلالة : أنَّ هذا الأثر يدل على أنَّ العدد الذي تنعقد به الجمعة هو أربعون رجلاً ، فاقتصر عليه إذ التجميع تغيير فرض فلا يصار إليه إلّا بنص أو اتفاق، ولم يثبت ذلك ـ ـ مّّا يدل على عدم انعقاد الجمعة بأقل من هذا العدد) (०)

يناقش : بأنّه إنْ صح هذا الأثر فإنَّ بلوغهم هذا العدد وقع اتفاقاً لا قصداً فلا يصح الاستدلال به ، فلم يقل

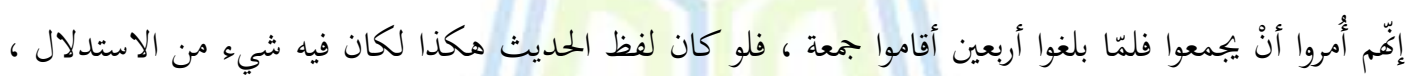
أمّا والحالة هذه فليس فيه شيء من الاستدلال . ثانياً : عن عبد الرحمن بن كعب بن مالك وكان قائد ابيه بعدما ذهب بصره عن ابيه كعب بن مالك أنّه كان إذا سمع النداء يوم الجمع ترحم لأسعد بن زرارة فقلت له : إذا سمعت النداء.

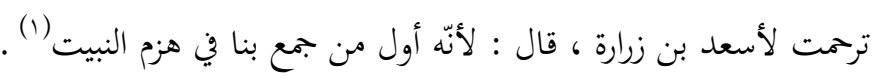

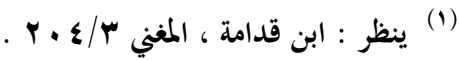

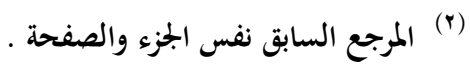

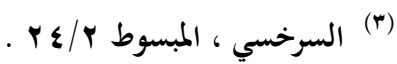

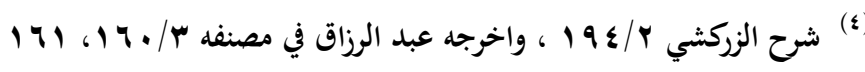

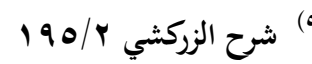

ro

Doi:10.37940/RJIS. 2021.2.1.2 


$$
\begin{aligned}
& \text { من حرة بني بياضة(r) في نقع يقال له : نقيع الخضمات(r)، قلت : كم أنتم يومئذ ؟ قال : أربعون (؟). } \\
& \text { وجه الدلالة : إذ دل هذا الأثر على أنَّ أول جمعة جمعت في المدينة كان عدد من جمع بهم أربعين مّّا يدل على أنَّ } \\
& \text { هذا العدد هو العدد الذي تنعقد به الجمعة . } \\
& \text { يناقش من وجهين : }
\end{aligned}
$$

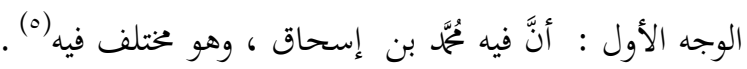
الوجه الثاني : أنَّ هذا العدد وقع اتفاقاً لا قصداً فلا يصح الاستدلال به ، لأنه لمج ينص على أفم أمروا بإقامة

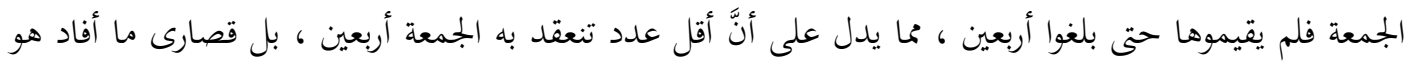
أنَّ العدد الذي أقيمت به أول جمعة في المدينة بناء على هذا الأثر هو أربعون .

ثالثاً : عن جابر بن عبدالله قال : مضت السنة أنَّ في كل ثلاثة إمام أو في كل أربعين فما فوق ذلك جمعة وأضحى

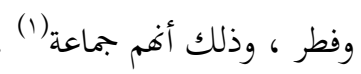

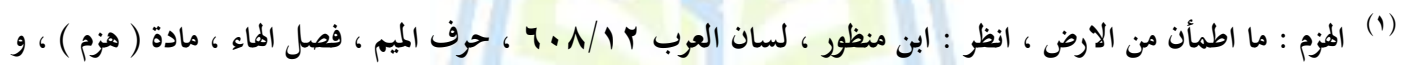

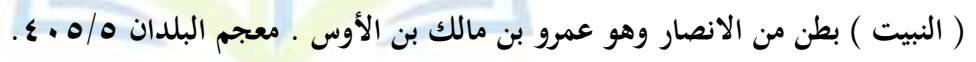

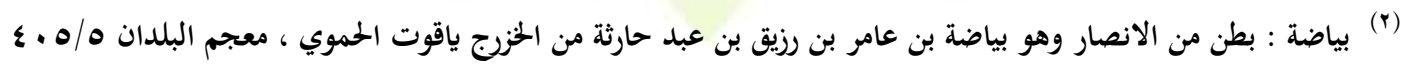

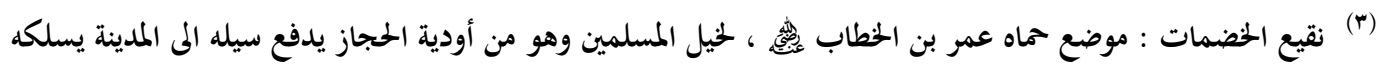

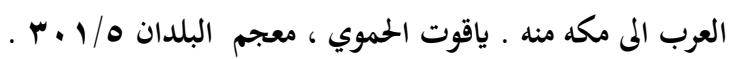

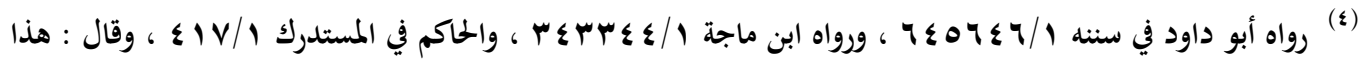

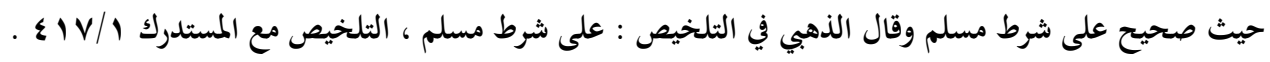

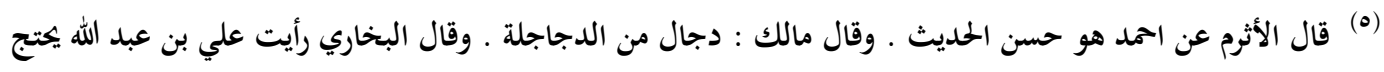

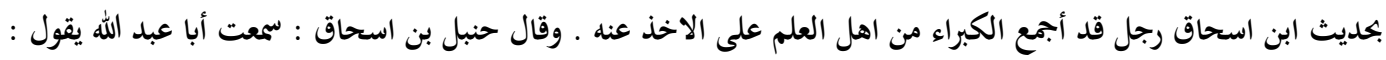

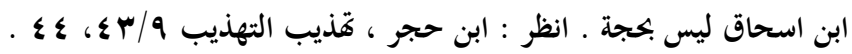

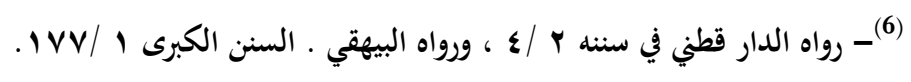

rד

Doi:10.37940/RJIS. 2021.2.1.2 


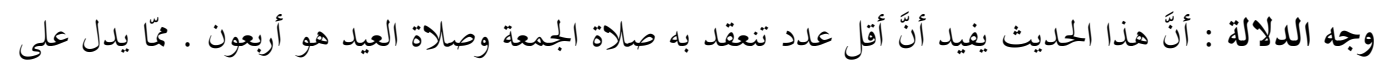

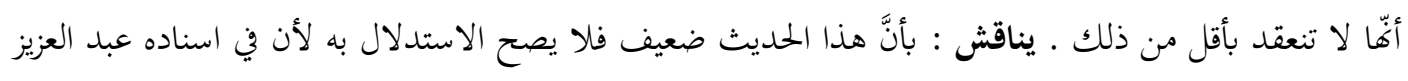

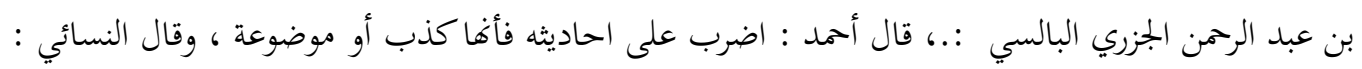
ليس بثقة وقال الدار قطني: منكر الحديث ـ وقال ابن حبان : لا يجوز أن يجتج به (r). دليل القول الثالث :

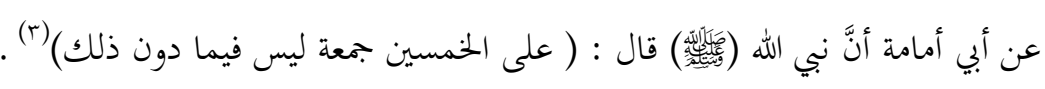

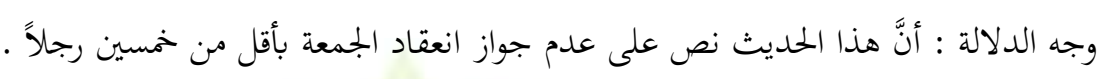

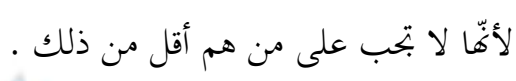

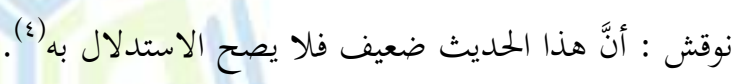
أدلّة القول الرابع:

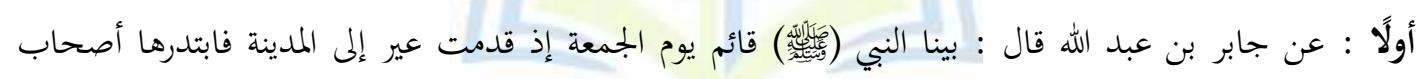

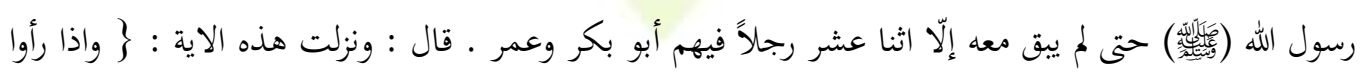

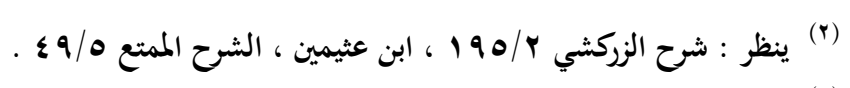

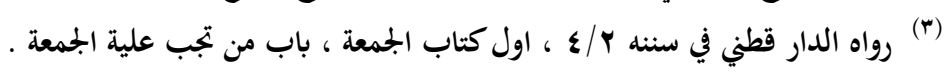

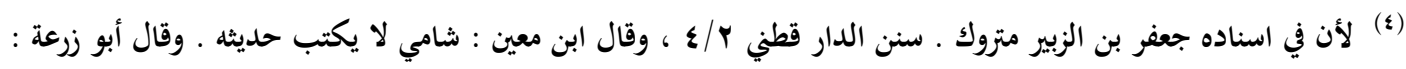

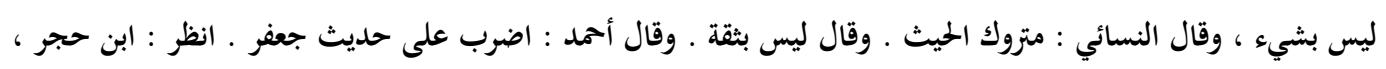

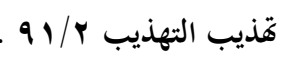

re

Doi:10.37940/RJIS. 2021.2.1.2 


$$
\text { تجارة أو لهواً انفضوا اليهاج (1)(r) (1) }
$$

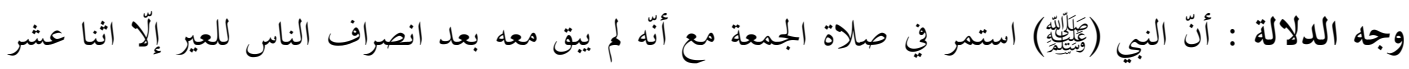

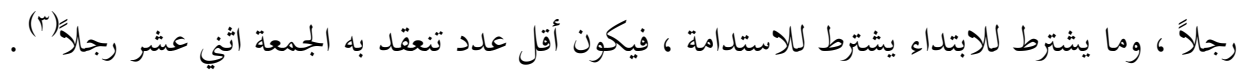

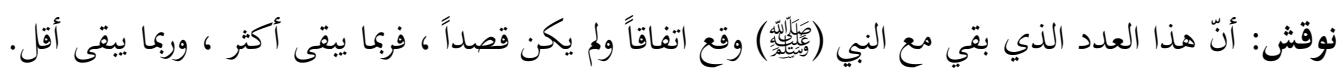
فلا يكون فيه دليل على أنّ أقلَّ عدد تنعقد به الجمعة اثنا عشر رجلاً .

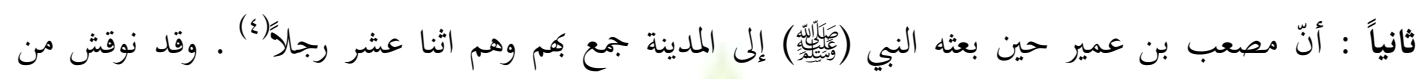
وجهين :

$$
\text { الأول : أنّ هذا لا يصح : إسناده فلا يصح الاستدلال به(o). }
$$

الثاني : أنّه لو صح فإنَّه لا يكون فيه دليلٌ على أنّ أقل عدد تنعقد به الجمعة اثنا عشر ، لأنا نقول: إنَّ هذا العدد

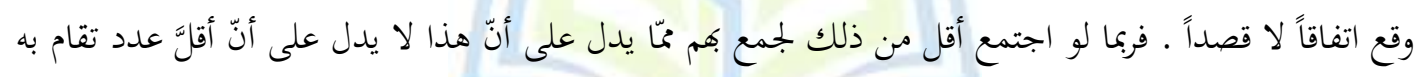
الجمعة اثنا عشر (؟).

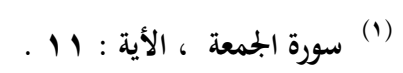

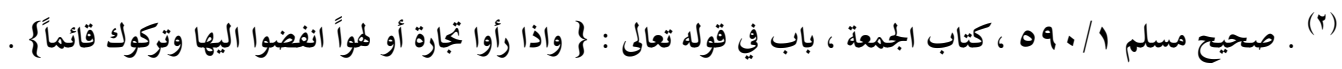

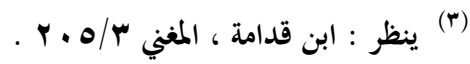

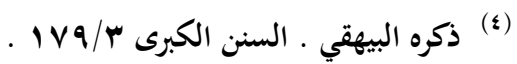

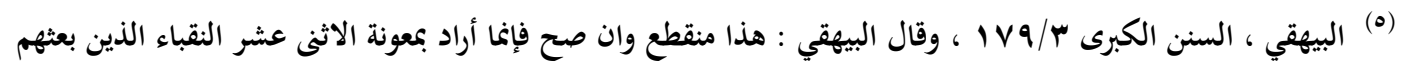

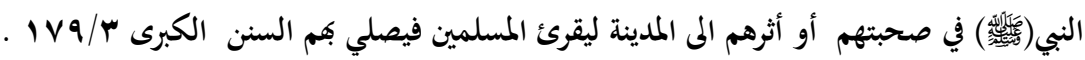

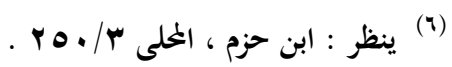

rᄉ

Doi:10.37940/RJIS. 2021.2.1.2 
أولاً : قال الله تعلى: \}يا أيها الذين آمنوا اذا نودي للصلاة من يوم الجمعة فاسعوا الى ذكر الله وذروا البيع ..\{ (1). وجه الدلالة : أنّ ما ذكر في الآية يقتضي منادياً وذاكراً وهو المؤذن والإمام والاثنان يسعون لأنَّ قوله : فاسعوا لا يتناول إلّا المثنى ، ثم ما دون الثلاثة ليس بجمع متفق عليه فإنَّ أهل اللغة فصلوا بين التثنية والجمع ، فالمثنى وإنْ كان فيه معنى الجمع من وجه فليس بجمع مطلق واشتراط الجماعة ثابت مطلقاً (r) . يناقش: أنّ الخطاب في الآية لعموم المؤمنين بوجوب إقامة صلاة الجمعة إذا نودي لها ـ وأقل ما تتجه له صيغة

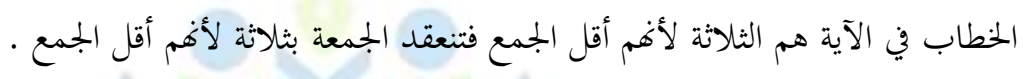

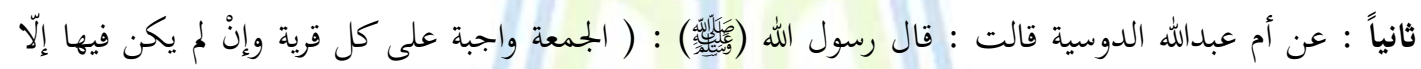
(r)

وجه الدلالة : أنّ هذا الحديث أثبت أنّ الجمععة تقام في القرية وإنْ لم يكن فيها إلّا أربعة ، وهذا يدل على أنَّ أقل عدد تنعقد به الجمعة هو اربعة أربعة وإنْ كان أقلَّ من ذلك فلا تنعقد به .

يناقش : أنّ هذا الحديث لا يجوز الاحتجاج به لأنَّ فيه معاوية بن يهيى ومعاوية بن سعيد وهما بجهولان(؟).

$$
\begin{aligned}
& \text { (1) سورة الجمعة ، الآية : } 9 \text {. . }
\end{aligned}
$$

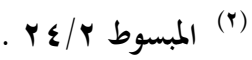

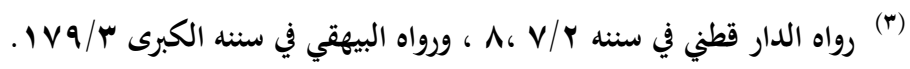

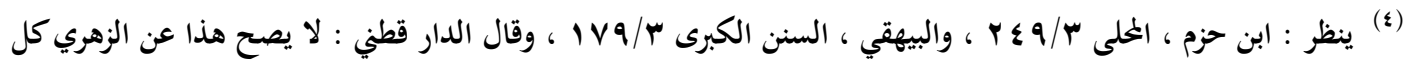

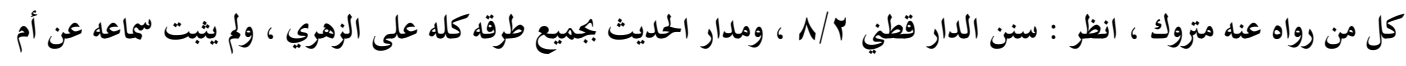
rq 


\section{ثالثاً : الأربعة عدد يزيد على أقل الجمع المطلق أشبه الأربعين (1) .}

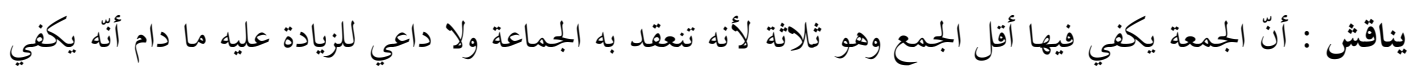

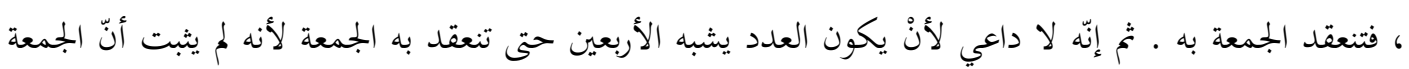

$$
\text { لا تلعقد إلّا بالأربعين . }
$$

إنّ الاثنين جماعة فيحصل الاجتماع ، ومن المعلوم أنّ صلاة الجماعة في غير الجمعة تنعقد باثنين بالاتفاق، والجمعة كسائر الصلوات فمن ادعى خروجها عن بقية الصلوات ، وأنّ جماعتها لا بد فيها من ثلاثة فعليه الدليل (r). نوقش : أنه لابد في صلاة الجمعة من جماعة تستمع الخطبة من الخطيب وأقلها اثنان والخطيب هو الثالث : فيتبين أنه لابد في صلاة الجمعة من ثلاثة خطيب ومستمعين وإنَّ الاثنين لا يكفيان ، لأنَّ أحدهما يكون خطيباً والآخر

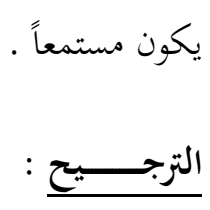

بعد الاطلاع على هذه المسألة والنظر في الأقوال الواردة فيها ومعرفة أدلة هذه الأقوال ، ومناقشة ما يحتاج إلى مناقشة من هذه الأدلّة تبين لي - والله أعلم بالصواب -إنَّ القول الراجح هو القول الأول وهو أنَّ الجمعة تنعقد

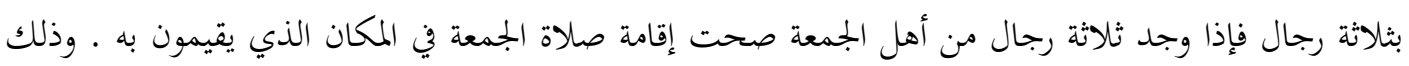

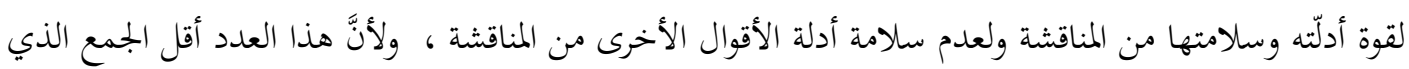

عبد الله الدوسية ، فالحديث مع ضعف رواته منقطع أيضاً ، فلا ينتهض للاحتجاج به ، مُحمَّم آبادي ، التعليق المغني على الدار

$$
\begin{aligned}
& \text { قطني V/r }
\end{aligned}
$$

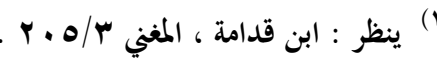

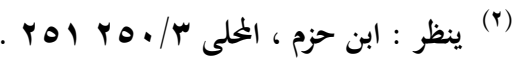

$\varepsilon$. 
يككن أنْ يحصل به اجتماع ، ولاسيّما حينما يتقدم الإمام للخطبة والصلاة فيكون خلفه اثنان وبالتالي تكتمل الجماعة ويحصل الاجتماع ، والله أعلم .

المطلب الثالث: حكم الحطبة بغير اللغة العربية اختلف الفقهاء في هذه المسألة على ثلاثة أقوال :

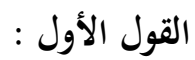

أغا لا تصح بغير اللغة العربية لغير الحاجة ، وتصح للحاجة ، وهذا قول عند الشافعية(1)، ولا تصح الخطبة بغير

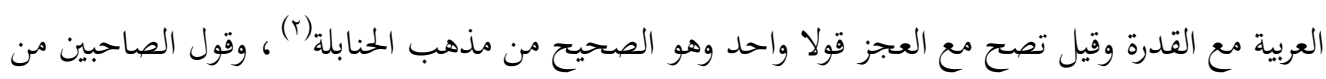
الحنفية) القول الثاني : - n

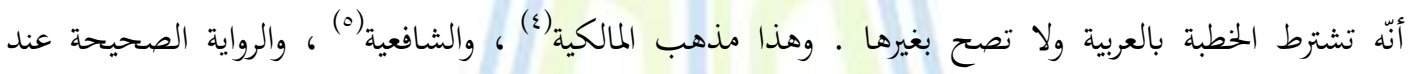
الحنابلة) (7)

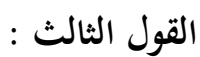
أنّه يستحب الخطبة بالعربية ويصح بغيرها ـ وهذا قول المعتمد عند الحنفية(V) ، وقول عند الشافعية(1) ، ورواية عند الحنابلة)(r)

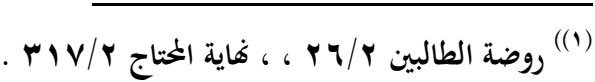

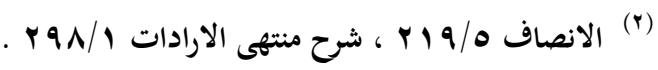

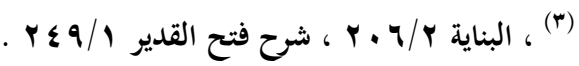

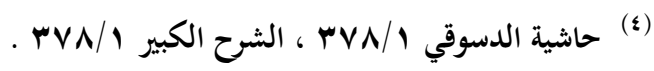

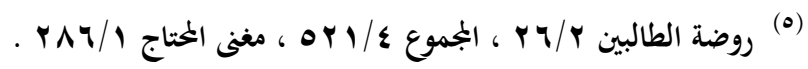

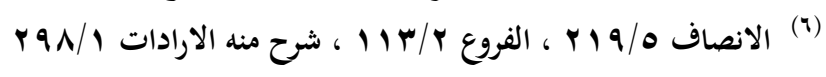

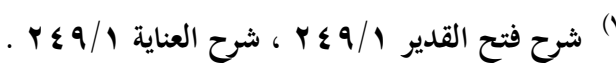

«)

Doi:10.37940/RJIS. 2021.2.1.2 


$$
\text { الأدلة - ادلة القول الاول }
$$

اولا: قوله تعالى :- (قل يا أيها الناس إني رسول الله اليكم جميعا) (r)

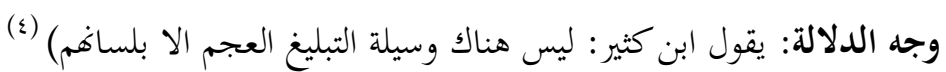

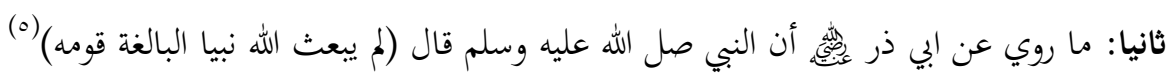

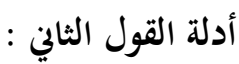

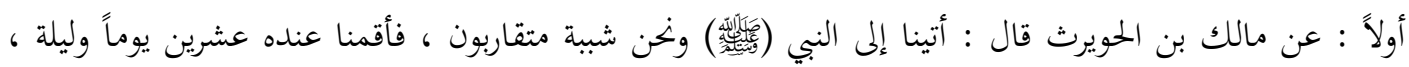

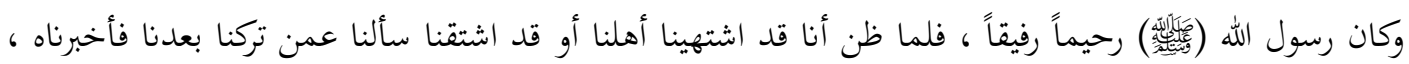
قال : ( ارجعوا إلى أهليكم فأقيموا فيهم ، وعلموهم ومروهم ، وذكر أشياء أحفظها أو لا أحفظها ، وصلوا كما

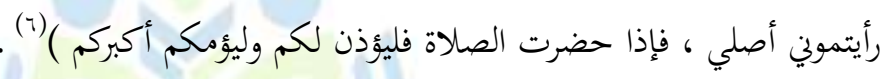

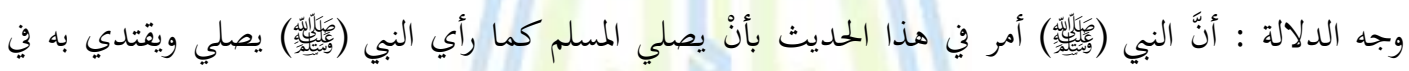

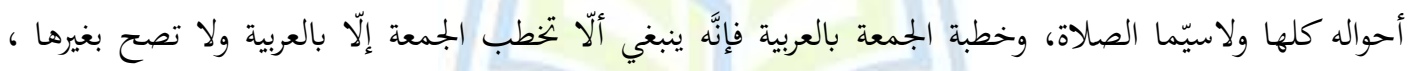
اقتداء بالنبي (

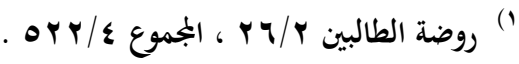

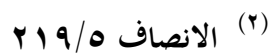

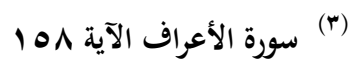

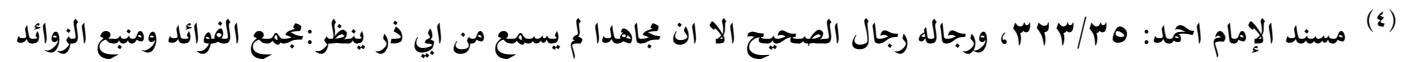

$$
\begin{aligned}
& \text {. }\{r / V \text { : } \\
& \text { ينظ (o) }
\end{aligned}
$$

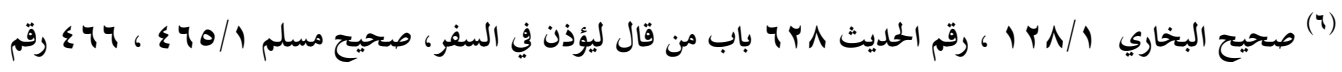

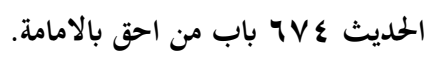




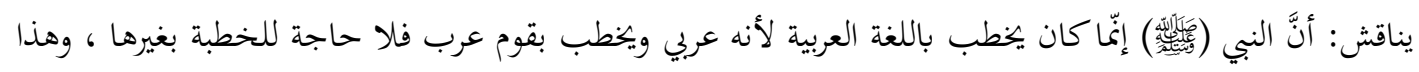

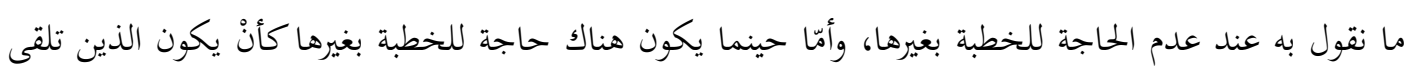

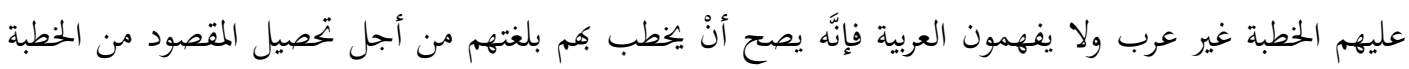
وهو الوعظ والإرشاد والنصح ، مّّا لا يتحصل لوقلنا بوجوب الخطبة بالعبية لهم .

ثانياً: إنّا نقول بوجوب الخطبة باللغة العربية لاتباع السلف والخلف إذ لم يعهد منهم الخطبة بغير العربية(1). يناقش : أنَّ السلف والخلف الذين ذكرتم إنّا كانوا يخطبون بأناس يعرفون العربية ، وهذا مما لا شك فيه أنّه ينبغي الخطبة في مثل هذه الحالة باللغة العربية لعدم الحاجة للخطبة بغيرها .

ثالثأ: إنَّ الخطبة ذكر مفروض فيتشرط فيها أنْ تكون باللغة العربية كتكبيرة الإحرام والتشهد ونوها(r). يناقش : أنّه لا يسلم لكم أنّه يلزم أنْ تكون جميع الأذكار المفروضة باللغة العربية لأنّه يلزم من هذا القول إثبات فرضية تعلم اللغة العربية على جميع المسلمين وهذا قول مرجوع لقول الله تعالى \} وما كان المؤمنون لنفروا كافة

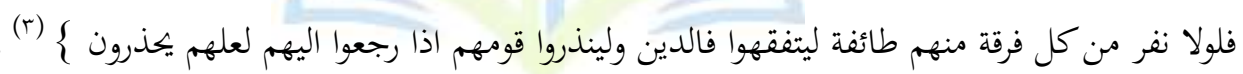
وبناء على هذا نقول بعدم وجوب تعلم اللغة العربية على جميع المسلمين فإذا قلنا بهذا القول فإنّا نقول أنهّ

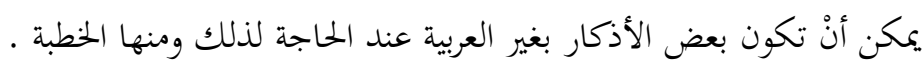

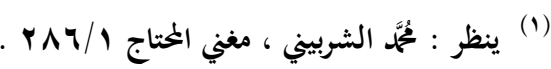

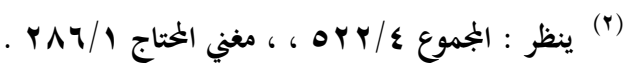

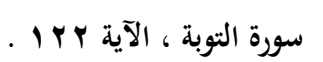

$\varepsilon r$

Doi:10.37940/RJIS. 2021.2.1.2 
أنَّ المقصود من الخطبة الوعظ وهو حاصل بكل اللغات فتصح الخطبة بأي لغة كانت(1).

يناقش : أنَّ الأصل في الخطبة أنْ تكون باللغة العربية إذا كان المستمعون يفهموها ويعرفوها

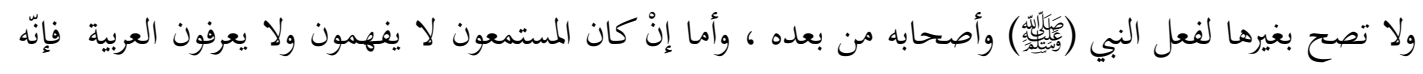
لا بأس من الخطبة بغيرها للحاجة لذلك.

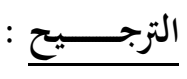

بعد النظر في الأقوال الواردة في هذه المسألة والاطلاع على أدلتها ومناقشة ما لم يستقيم من هذه الأدلة تبين لي

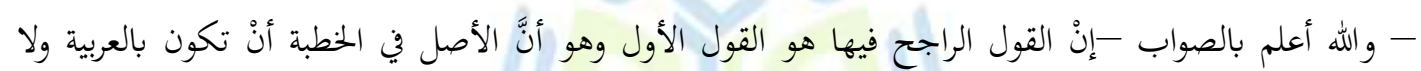
تصح بغيرها عند عدم الحاجة لذلك ، وتصح بغيرها عند الحاجة لذلك بشرط قراءة الآيات باللغة العربية ثم ترجمة معانيها بلغة الخطبة ـ وذلك لقوة أدلته وسلامتها من المناقشة ولضعف أدلة الأقوال الأخرى وعدم سلامتها من

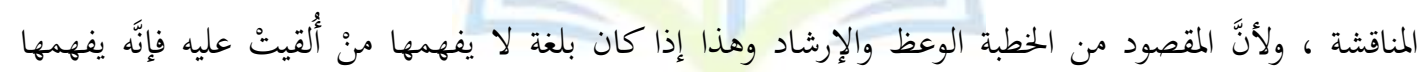
ويستفيد منها ويتعظ بها ، ثم إنَّ كثير من المسلمين في العصر الحاضر لا يعرفون العربية وفي إلزامهم بتعلم العربية

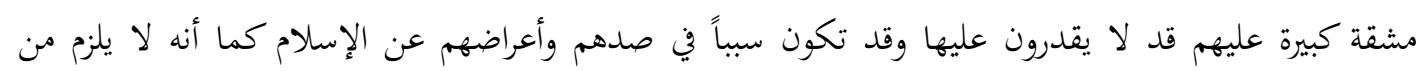
الإسلام أنْ يكون الإنسان متقناً للغة العربية ، فلا يعقل بعد هذا أنْ يمنع القاء الخطبة بغير العربية وتفويت فوائدها المرجوة منها بسبب أمر ليس في مقدور المسلم العجمي تعلمه وتحصيله.

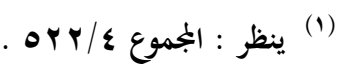

$\varepsilon \varepsilon$

Doi:10.37940/RJIS. 2021.2.1.2 


\section{المبحث الثاني: حكم صلاة العيدين للمغتربين}

يمر على المغتربين في وقت غربتهم أيّام عيد الفطر وعيد الأضحى وهي أيّّام شرع الله فيها صلاة العيد وجعلها فيها

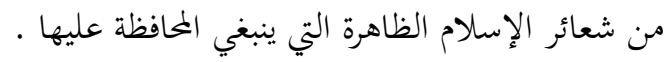
فما حكم صلاة العيد للمغتربين؟ المطلب الأول: القائلون بانما فرض كفاية لماند

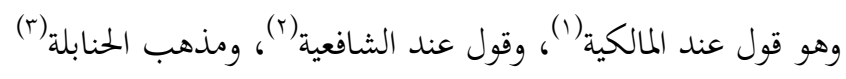

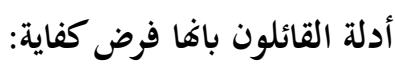

استدلوا بأدلة على الوجوب في الجملة ومنها :

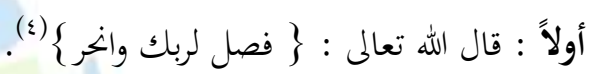

وجه الدلالة : أنَّ هذه الآية أمرت بأداء صلاة العيد والأمر يقتضي الوجوب إلّاّ بصارف يصرفه من الوجوب إلى الندب ولا صارف هنا.

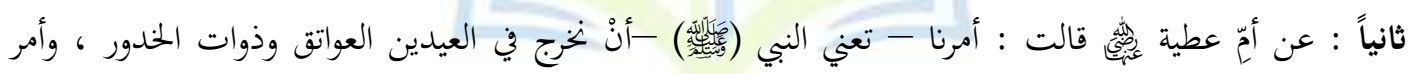

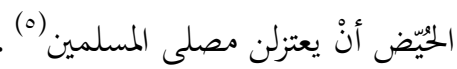

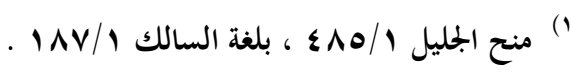

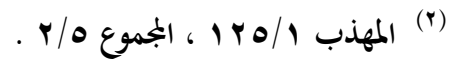

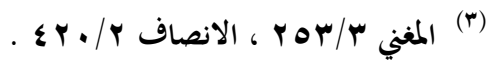

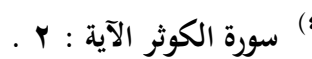

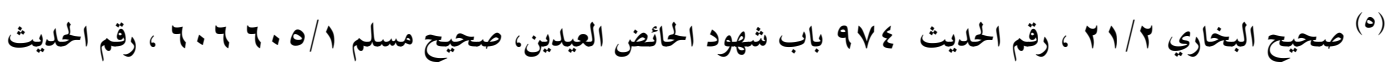

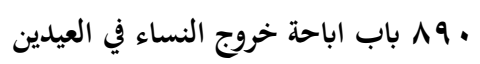
¿० 
وجه الدلالة : أنَّ الأمر يقتضي الوجوب إلّا بصارف يصرفه من الوجوب إلى الندب ولا صارف هنا وإذا كان النبي

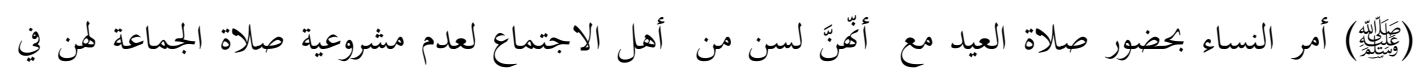

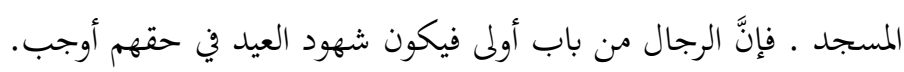

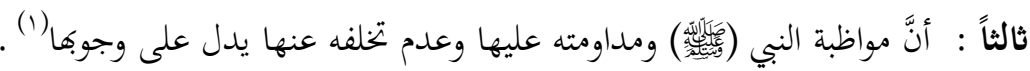
يناقش : أنَّ الأصل في المداومة على الشيء إذا لم يكن فيه أمر الاستحباب(r). رابعاً : أنَّ صلاة العيد من أعلام الدين وشعائره الظاهرة فكانت واجبة كالجمعة(r).

يناقش : أنَّ من أعلام الدين وشعائره ما ليس واجباً على الأعيان بل هو واجب كفائي ، كالأذان والإقامة فليس كل ما كان من أعلام الدين وشعائره واجباً على الأعيان.

خامساً : أخّا لو لم تكن واجبه لم يجب قتال تاركيها كسائر السنن . يجققه أنَّ القتال عقوبة لا تتوجه إلى تارك

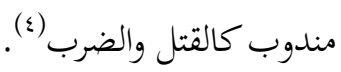

يناقش : أنه إنّما جاز قتال تاركيها لأها من شعائر الإسلام الظاهرة لايهوز لأي مجتمع تركها بالكلية ولذلك جاز

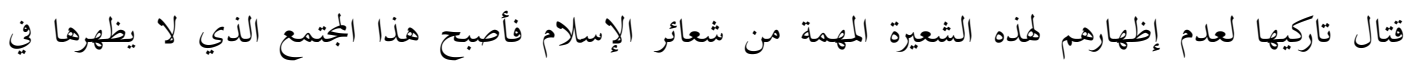

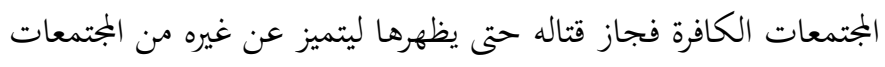

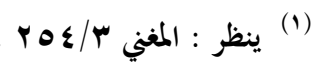

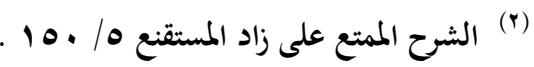

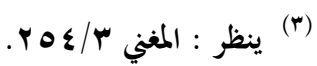

(5) المرجع السابق نفس الجزء والصفحة.

$\leqslant 7$

Doi:10.37940/RJIS. 2021.2.1.2 


\section{سادساً : أنَّ صلاة العيد شرعت لما الخطبة فكانت واجبة على الأعيان(1) وليست فرضاً كالجمعة .}

يناقش : أنَّ هذا قياس مع الفارق إذ إنّا تختلف عن الجمعة لأنَّ خطبة الجمعة واجبة واستماعها واجب بخلاف صلاة العيد فخطبتها غير واجبة واستماعها غير واجب. ما سبق من الأدلة دل على وجوب صلاة العيد في الجملة وأما أدلة عدم وجوبها على الأعيان فهي : أولاً : أنَّ صلاة العيد صلاة لا يشرع لها الأذان فلم تكن واجبة على الأعيان كصلاة الجنازة(r).

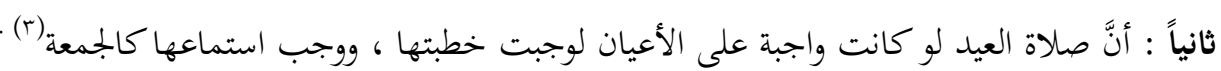
المطلب الثاني: القائلون بانما سنة مؤكدة

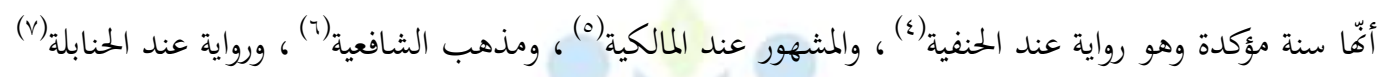

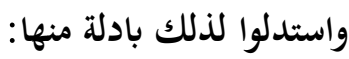

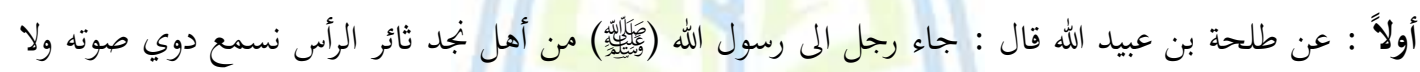

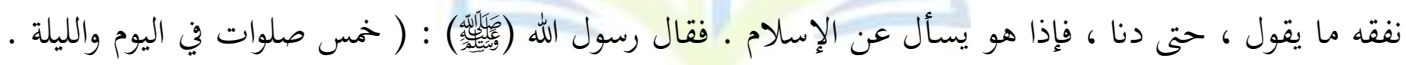

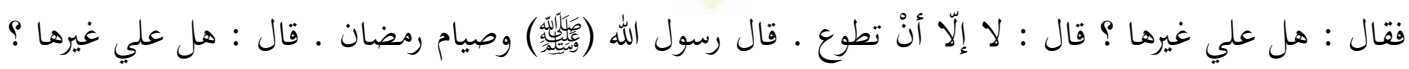

$$
\begin{aligned}
& \text { (1) (المرجع السابق نفس الجزء والصفحة. }
\end{aligned}
$$

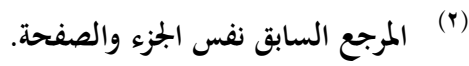

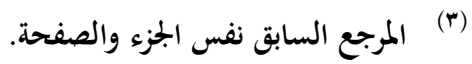

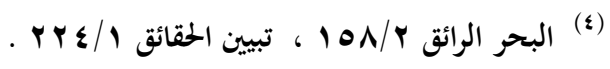

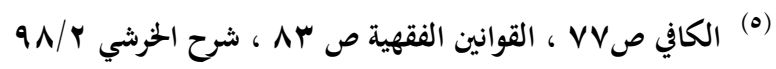

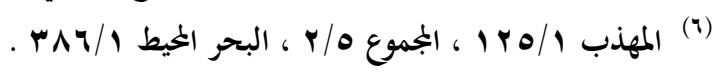

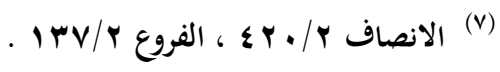

$\leqslant \vee$ 


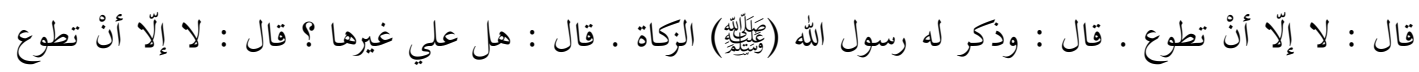

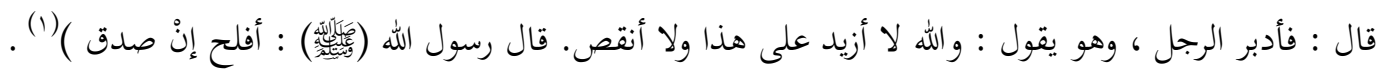

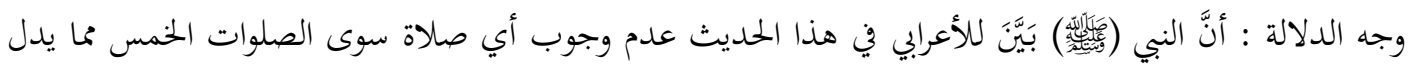
على سنية ما عداها من الصلوات ـ ومن ضمن الصلوات صلاة العيد فتكون سنة .

يناقش : أنه لا حجة لكم فيه لأنَّ الأعراب لا تلزمهم الجمعة لعدم الاستيطان فالعيد أولى (r).

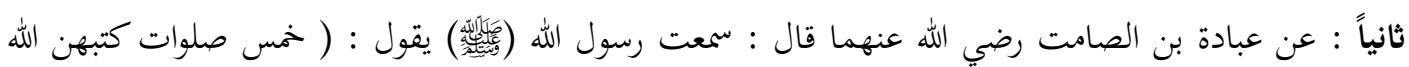

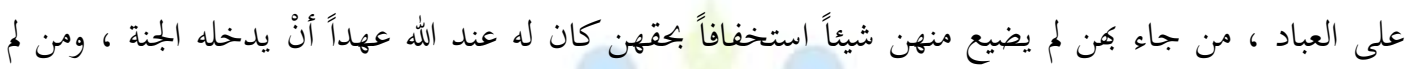

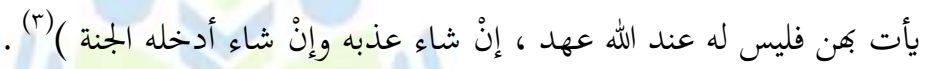

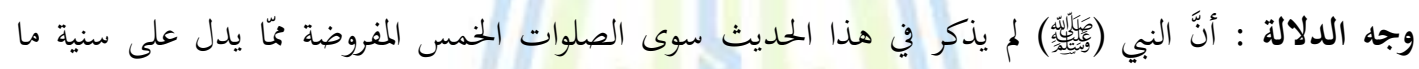

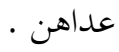

يناقش : أنَّ النبي () ووجوبها على الدوام وتكرارها في كل يوم وليلة ، وغيرها يجب نادراً ولعارض كصلاة الجنازة والمنذورة والصلاة

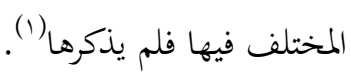

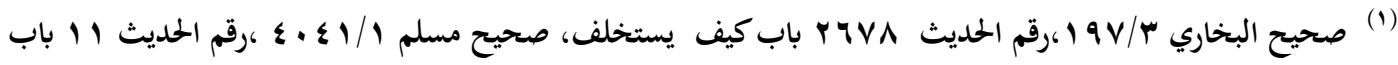

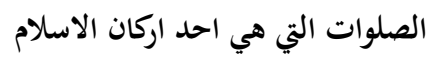

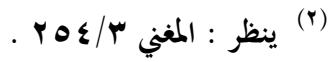

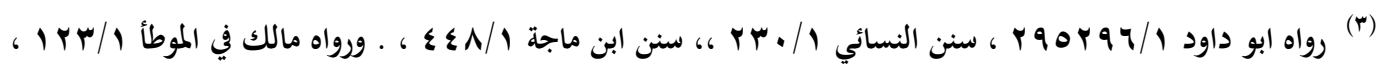

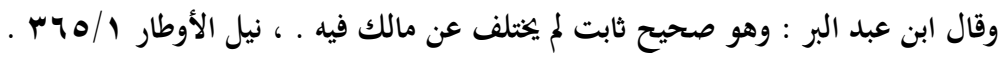
$\varepsilon \wedge$

Doi:10.37940/RJIS. 2021.2.1.2 
ثالثاً : أنَّ صلاة العيدين صلاة ذات ركوع وسجود لم يشرع لها أذان فلم بحب ابتداء بالشرع كصلاة الاستسقاء

$$
\text { والكسوف (r) }
$$

يناقش : أنَّ هذا القياس لا يصح لأنَّ كوها ذات ركوع وسجود لا أثر له ، بدليل أنَّ النوافل كلها فيها ركوع وسجود ، وهي غير واجبة ، فيجب حذف هذا الوصف لعدم أثره ، ثم ينقض قياسهم بصلاة الجنازة وينتقض بكل حال بالمنذورة (r)

المطلب الثالث: القائلون بانها واجبة على الاعيان

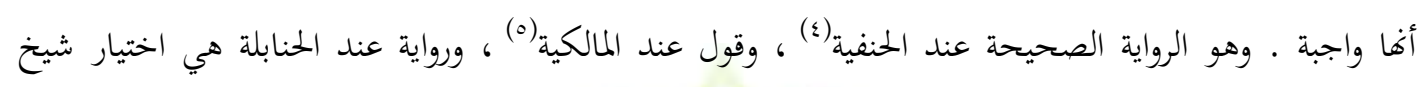
والإستلام ابن تيمية(؟) . استدل أصحاب هذا القول بعموم الأدلة التي دلت على وجوب صلاة العيد في الجملة(V)،

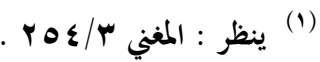

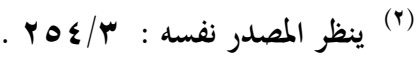

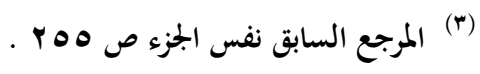

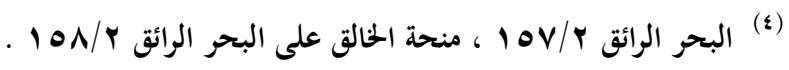

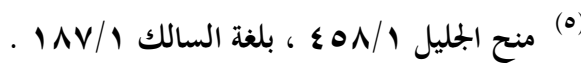

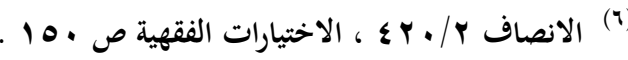

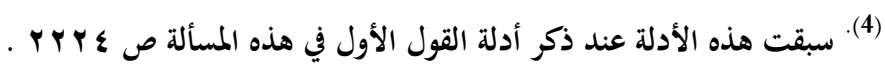


وقالوا بأها باقية على عمومها لعدم وجود دليل يخص أو يستثني بعض المسلمين دون بعض ، وقد سبق مناقشة ما يحتاج إلى مناقشته منها.

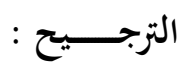

بعد النظر في هذه المسألة والاطلاع على الأقوال الواردة فيها ومعرفة أدلة هذه الأقوال ومناقشه ما يجتاج مناقشته

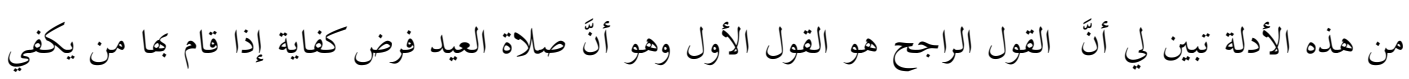

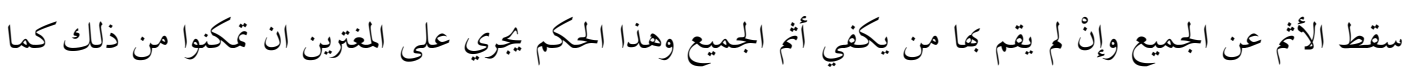
يجري على المسلمين في دار الاسلام.

ولانا لا يشرع لها الاذان فلم بحب على الاعيان كصلاة الجنازة ولاها لووجبت على الاعيان لووجبت خطبتها ووجب استماعها كالجمعة، والله أعلم.

\section{المبحث الثالث: حكم الجنائز للمغتربين المطلب الأول: حكم زيارة قبور المشركين}

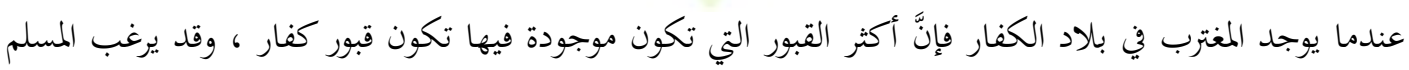

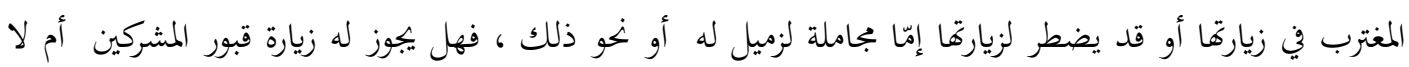

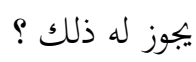
اتفق جمهور الفقهاء(1)، على أنّه يجوز للمسلم أنْ يزور قبور الكافرين والمشركين.

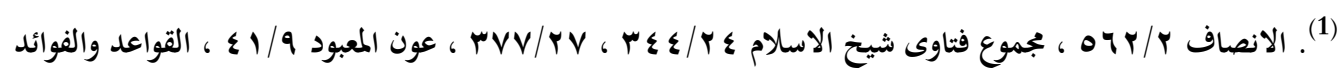

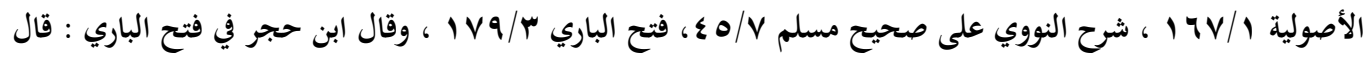

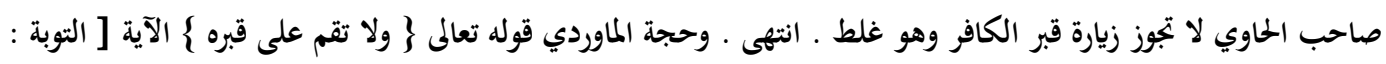

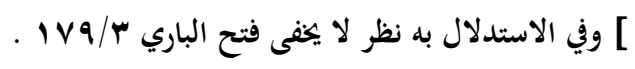

$\circ$.

Doi:10.37940/RJIS. 2021.2.1.2 


$$
\begin{aligned}
& \text { استدلوا على ذلك بما يأتي : } \\
& \text { الدليل الأول : }
\end{aligned}
$$

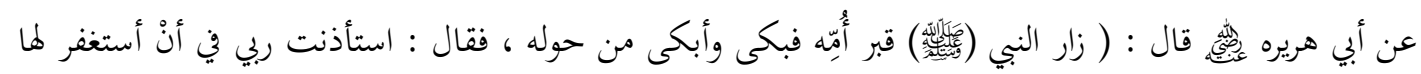

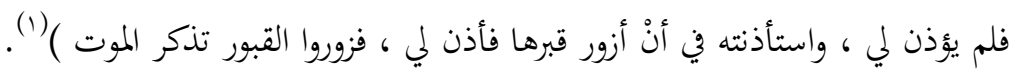

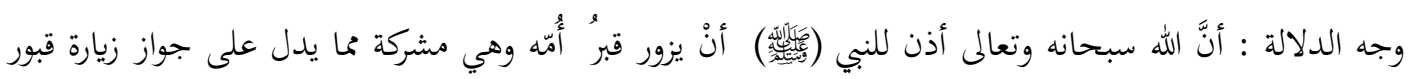

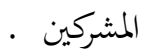

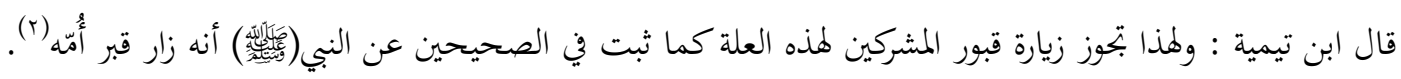
وقال النووي : فيه جواز زيارة المشركين في الحياة وقبورهم بعد الوفاة لأنّه إذا جازت زيارقم بعد الوفاة ففي الحياة أولى (r)

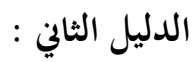

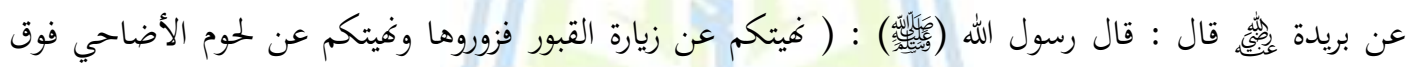

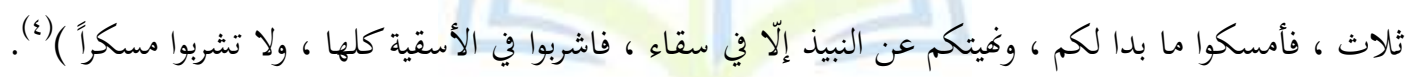

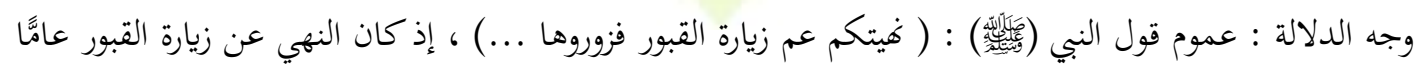
سواء كانت قبور مسلمين أو قبور كفار ، فجاء الإذن بزيارتا عام أيضاً فيشمل قبور المسلمين وقبور الكفار أيضاً .

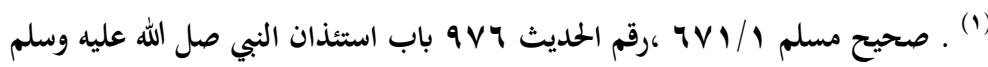

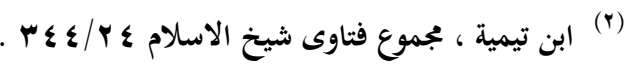

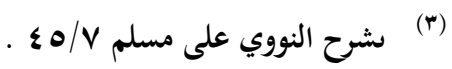

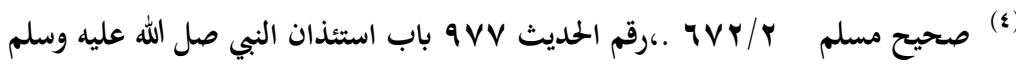

01

Doi:10.37940/RJIS. 2021.2.1.2 
الترجيح: والذي يبدو لي ان زيارة قبور الكافرين والمشركين للمسلم لا باس بها ولكن بشروط منها ان تكون الزيارة على سبيل الاتعاظ وان لا يسلم ولا يدعوا له ويشره بالنار ودليل ذلك ما جاء من حديث الاعرابي حينما سأله عن ابيه فقال له النبي صل الله عليه وسلم(حيثما مررت بقبر كافر فبشره بالنار)(1) المطلب الثاني: حكم الدفن في التابوت

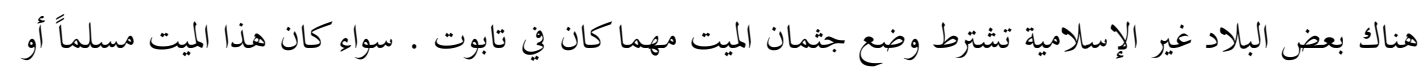

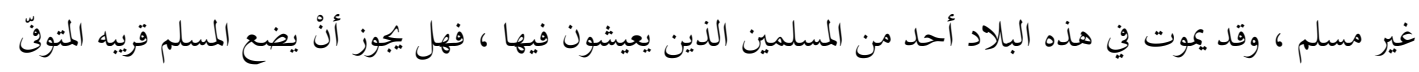

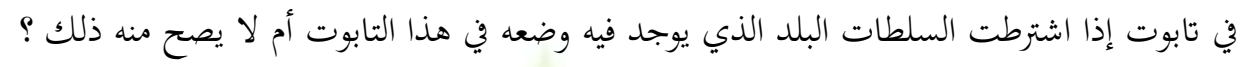

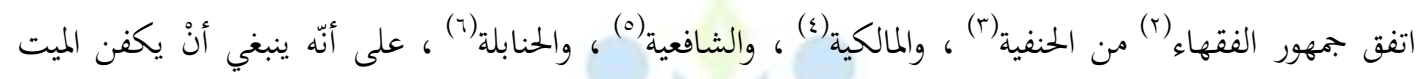

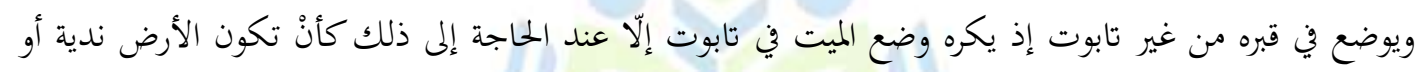

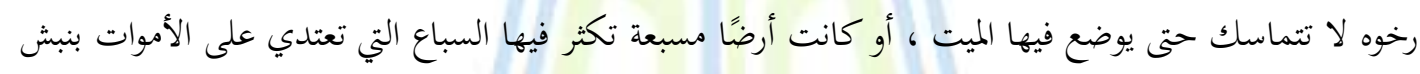
قبورهم.

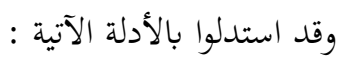

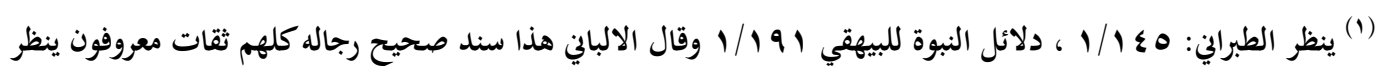

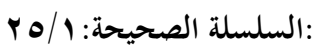

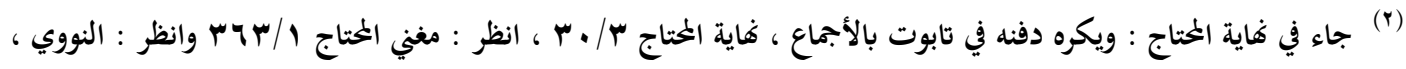

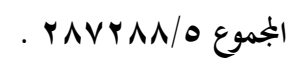

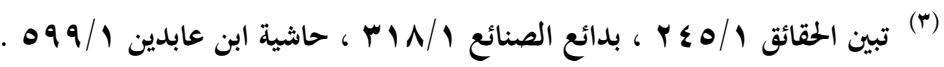

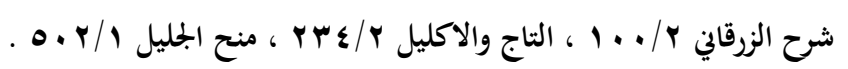

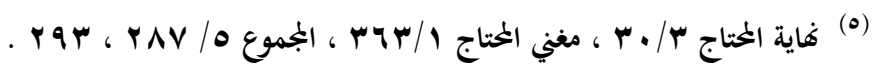

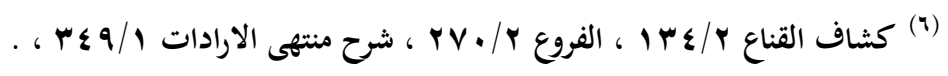
or 


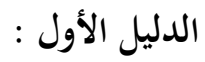

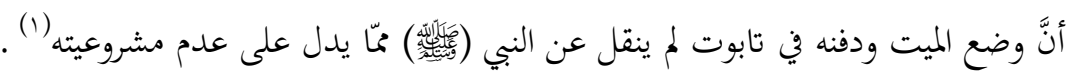

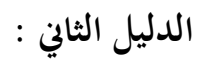

أنّ وضع الميت ودفنه في تابوت تشبه بالكفار إذ إنّه من عملهم وقد ورد النهي عن التشبه بكم (r). الدليل الثالث :

أنّ دفن الميت في الأرض أنشف لفضلاته إذ يعجل بنشوف فضلاته وتأخر إنتانه بخلاف وضعه في تابوت إذ إنّه يساعد على تأخر نشوف فضلاته وسرعه إنتانه (r).

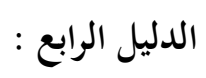

أنّ عدم إدخال التابوت معه في قبره ولا شيء مّّا مسته النار تفاؤلاً بألّا يمس الميت النار(؟).

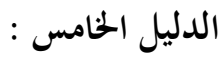

أنّ في الدفن في التابوت إضاعة مال مع عدم ورود ذلك عن السلف (م). الراجح: والذي يبدو لي في هذه المسألة انه لا يجوز الدفن في التابوت للأدلة التي استدل بها جمهور الفقهاء لكن اذ اضطرا أو أجبر على ذلك فلا بأس ان يضع المسلم قريبه في التابوت للدفن و الله اعلم

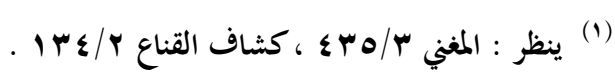

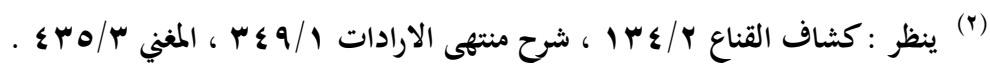

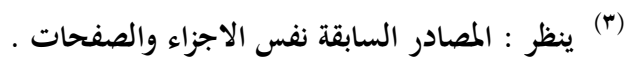

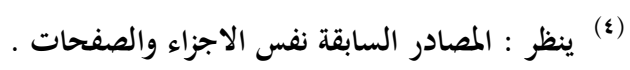

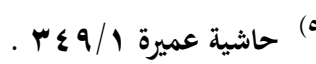

or

Doi:10.37940/RJIS. 2021.2.1.2 
المطلب الثالث: حكم دفن المسلم في مقابر الكفار قد يموت المسلم المغترب في بلد اغترابه ولا يستطيع ورثته دفنه في مكان خاص بلمان بالمسلمين لعدم وجود مقابر خاصة بالمسلمين في البلد الذي مات فيه أو لا يجدون بلداً من بلاد المسلمين تسمح سلطاته باستقبال جثمان الميت المسلم لدفنه في مقابرها.

فهل يجوز دفنه في مقابر الكفار أم لا يجوز ذلك ؟

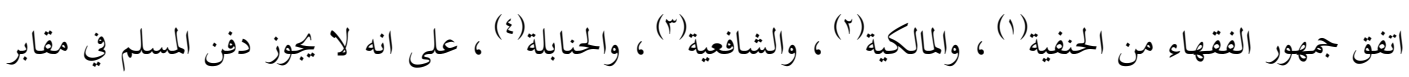
الكفار ، إلّا عند الضرورة كأن يموت المسلم في بلد كفار لا يوجد فيه مقبرة خاصة بالمسلمين ، ولا يستطيع ورثنه نقله إلى بلد من بلاد المسلمين لدفنه فيها لعدم قدرقم المالية على ذلك أو لأغم لا يجدون بلداً من بلاد المسلمين

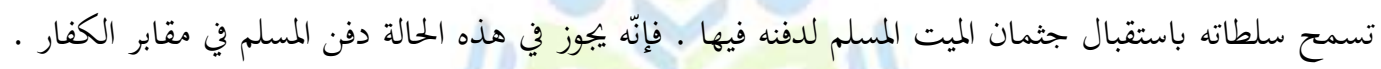
وهذا ما أفتى به بجلس مجمع الفقه الإسلامي التابع لمنظمة المؤتمر الإسلامي في دورة مؤتمره الثالث المنعقد بعمان

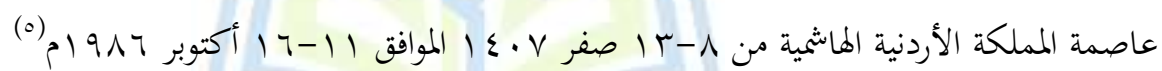

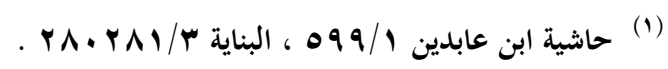

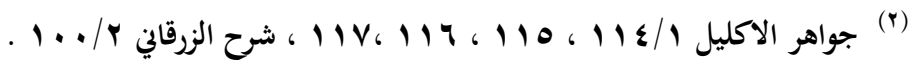

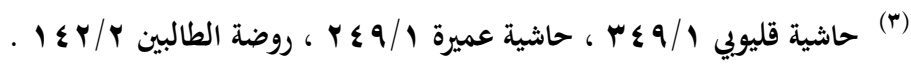

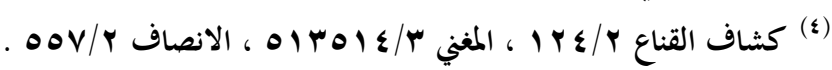

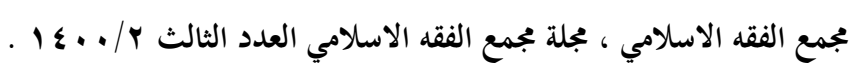

$0 \leqslant$

Doi:10.37940/RJIS. 2021.2.1.2 
الحمد لله والصلاة والسلام على رسول الله وعلى آلة وصحبه ومن والاه ...

إنَّ مّّا لا شك فيه ولا ريب أنَّ لكل شيء بداية ، وله في ذات الأمر فاية وهذا البحث من الأشياء التي كانت لها

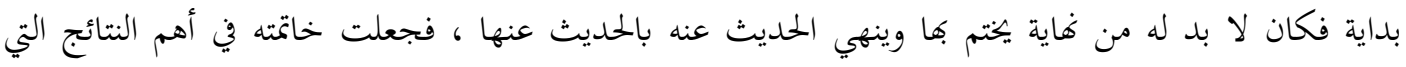

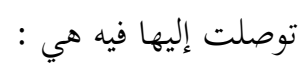
ا - أنّه لا يشترط إذن الإمام في صحة إقامة صلاة الجمعة سواء كان ذلك في بلاد المسلمين أم في بلاد الكافرين .

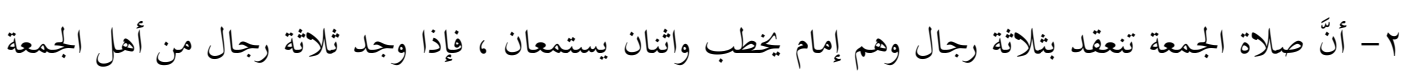
، صحت إقامة صلاة الجمعة في المكان الذي يقيمون فيه.

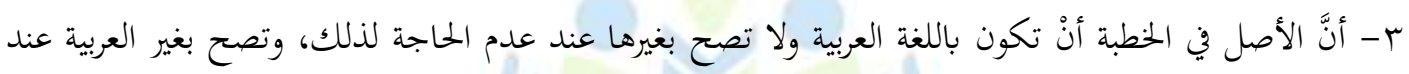

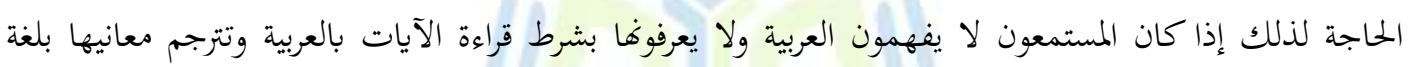
الخطبة . ع - أنَّ صلاة العيد فرض كفاية إذا قام بها من يكفي سقط الأتم عن الباقين ، وإنْ لم يقم مها من يكفي إثم الجميع.

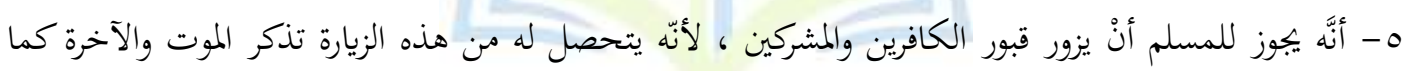

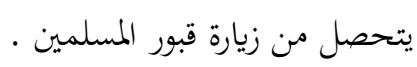

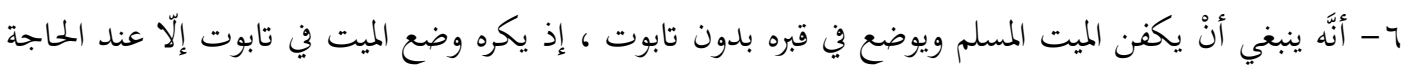

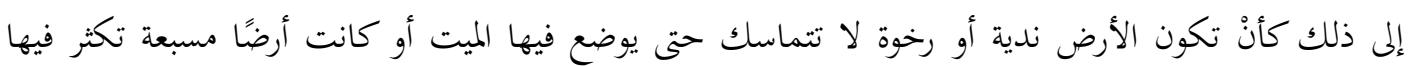

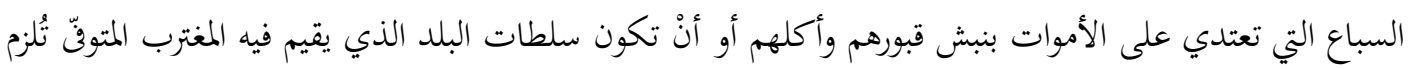

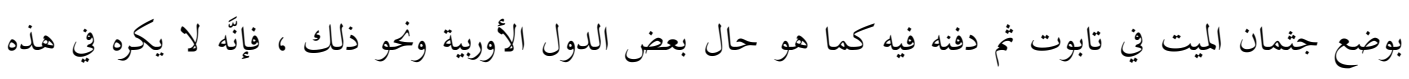

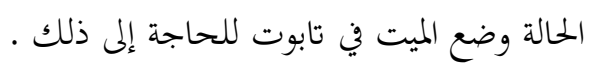
V- أنَّه لا يجوز دفن المسلم في مقابر الكفار إلّا عند الضرورة كأنْ يموت المسلم المغترب في بلد كفار لا لا يوجد فيه

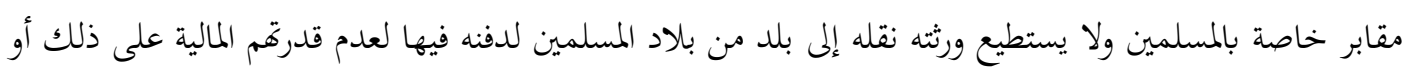

00

Doi:10.37940/RJIS. 2021.2.1.2 
أفّم لا يجدون بلداً من بلاد المسلمين تسمح سلطاته باستقبال جثمان الميت المسلم لدفنه فيها ، فإنّه يجوز في هذه

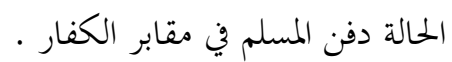
هذه هي أهم النتائج والثمرات التي تم التوصل إليها في هذا البحث المتواضع ، فأسأل الله العظيم ذا الوجه الكريم

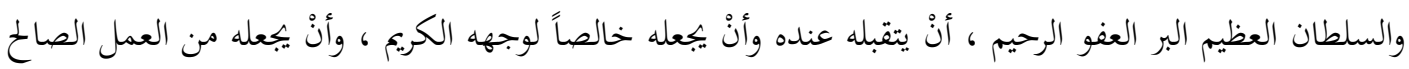
الذي يسر النظر إليه يوم القيامة ل...

$$
\text { وآخر دعوانا أنِ الحمد لله رب العالمين .... }
$$

وصلى الله وسلم وبارك على سيدنا يُحَّهَ وآله وصحبه أجمعين 


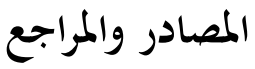

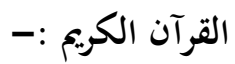

ا ـ الاختيارات الفقهية من فتاوى شيخ الاسلام ابن تيمية : ، أحمد بن عبد السلام ـ اختارها علي البعلي

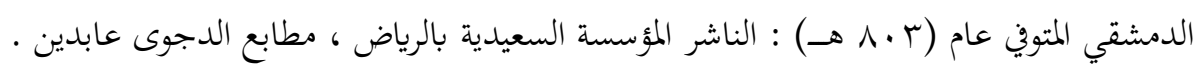

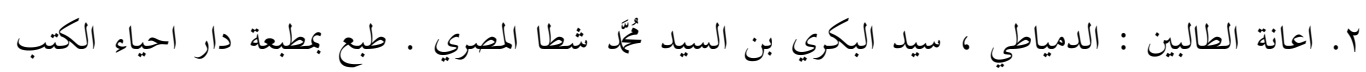
العربية ، عيسى البابي الحلبي

r. الأم الشافعي ، أبو عبد الله ثُمَّمَ بن إدريس ، المتوفي ( ع · ب هـ ) . الناشر دار المعرفة ، بيروت ، لبنان.

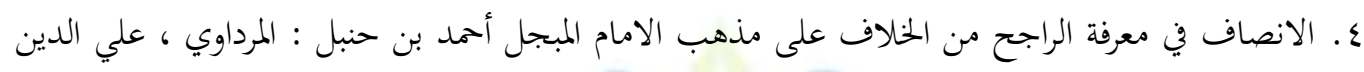

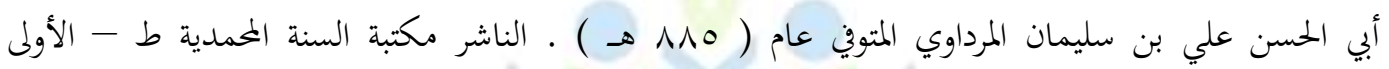

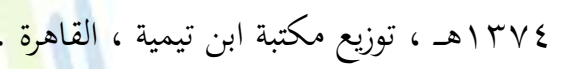

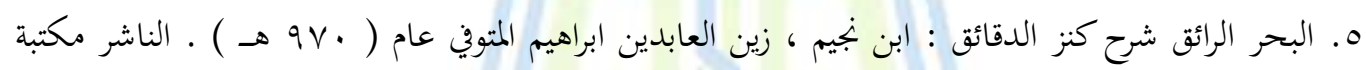
رشيدية ، باكستان ، المطبعة العربية .

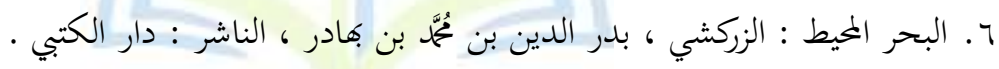

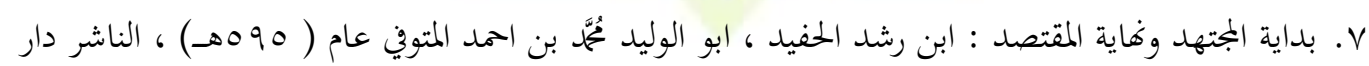

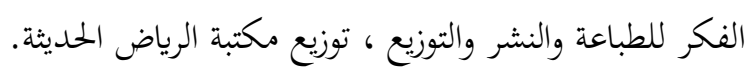

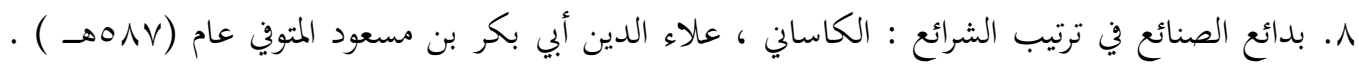

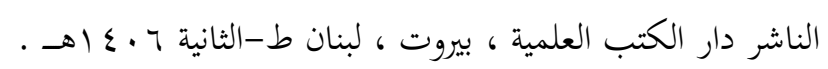

9. بلغة السالك لأقرب المسالك : الصاوي ، احمد بن يُمَّمَ . الناشر : شركة مكتبة ومطبعة مصطفى البابي

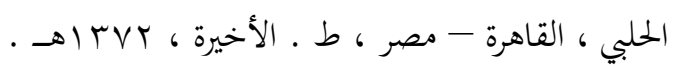

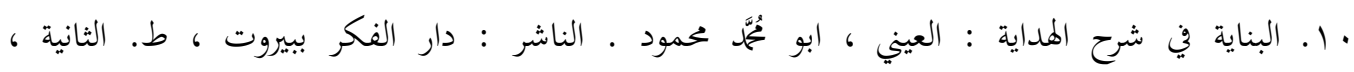
. $199 \cdot \mid-1 \leqslant 11$

or

Doi:10.37940/RJIS. 2021.2.1.2 
1ا. التاج والاكليل لمختصر خليل : المواق ، أبو عبد الله يُمَّم بن يوسف العبدري ، المتوفي عام (19ههـ ) .

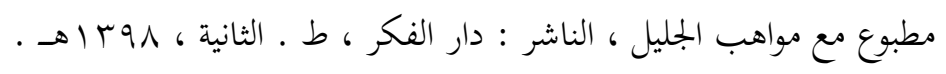

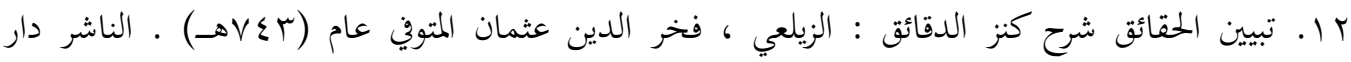

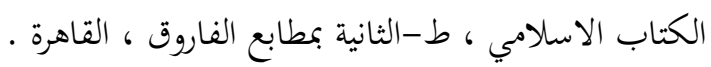

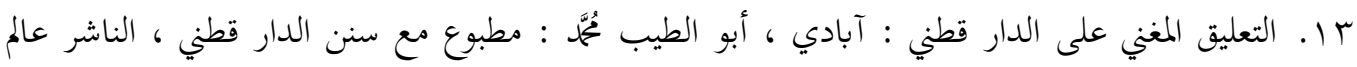

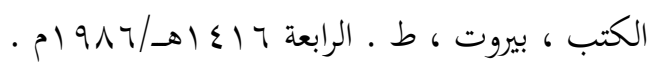

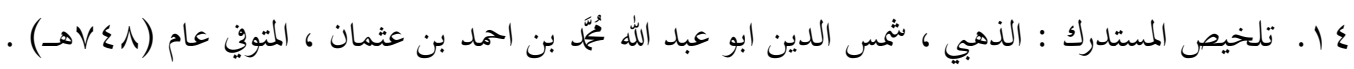

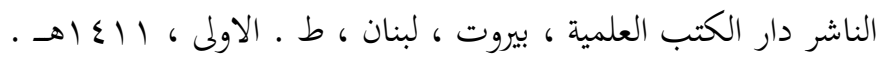

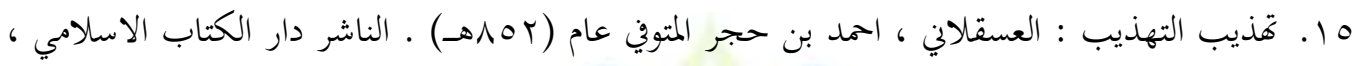

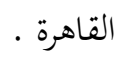

ا 1. . جواهر الاكليل شرح مختصر خليل : الازهري ، صالح عبد السميع الآبي . الناشر دار الفكر للطباعة والنشر والتوزيع ، بيروت . جواهر الاكيل شرح

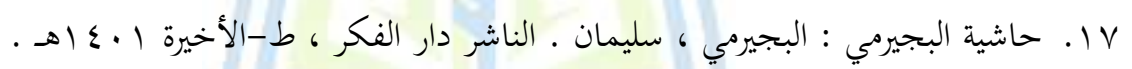

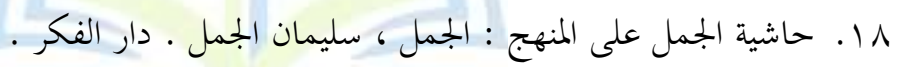

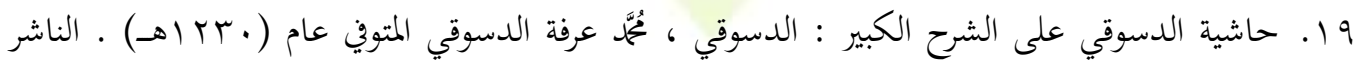

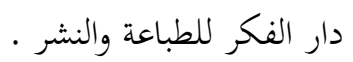

• r. حاشية العدوي : العدوي ، علي . مطبوع مع شرح الخرشي ، الناشر : دار الكتاب الاسلامي لإحياء

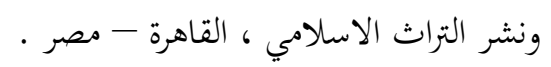

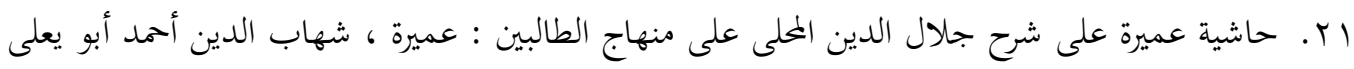

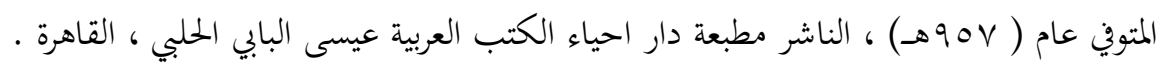

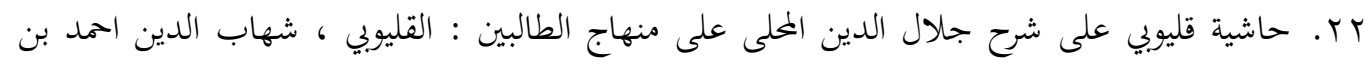

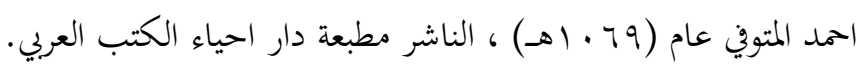




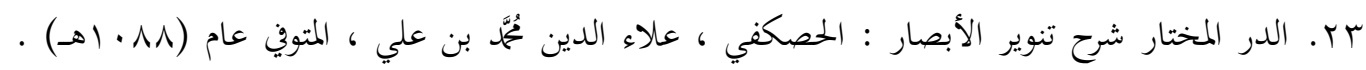

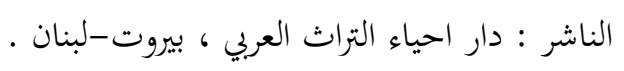

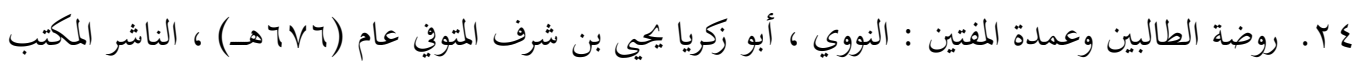

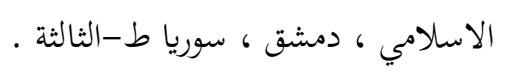

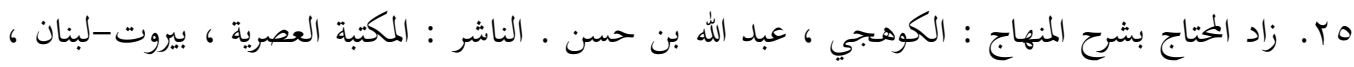

$$
. \rightarrow 1 \leqslant .9
$$

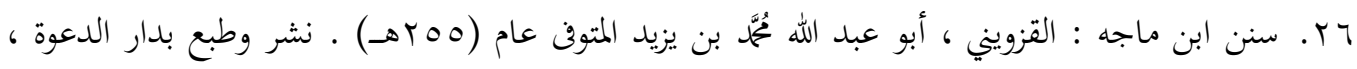

$$
\text { اسطنبول ، تركيا . أ. }
$$

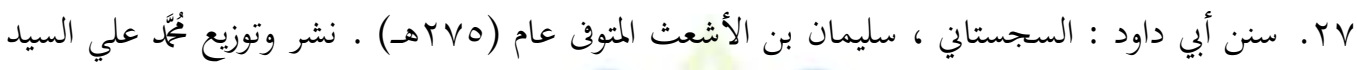

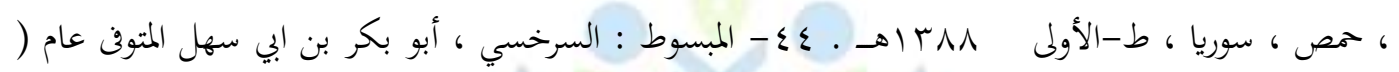

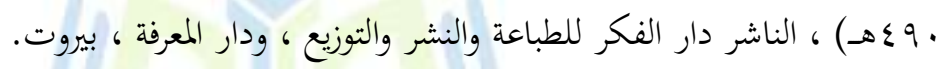

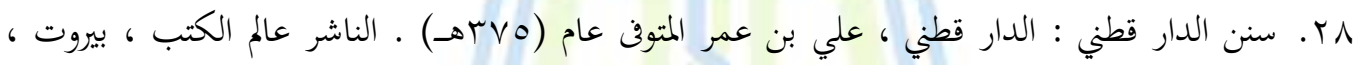

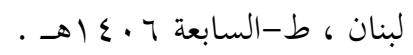

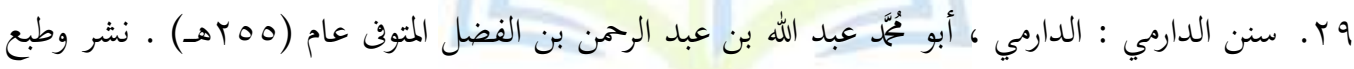

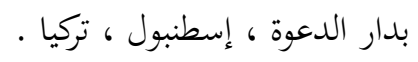

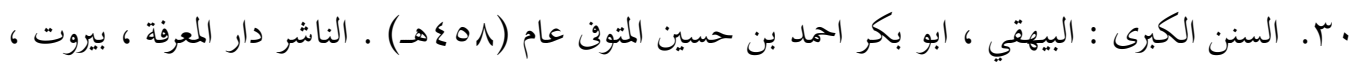

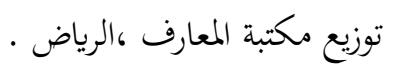

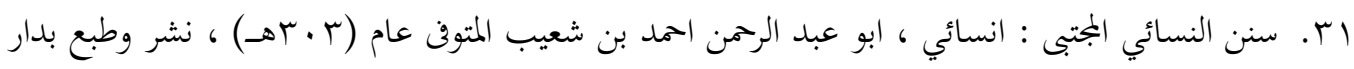

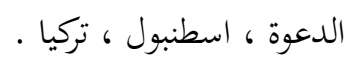

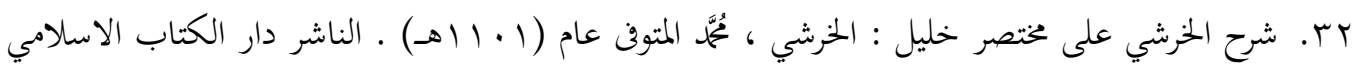

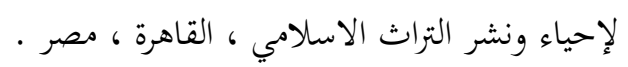


r r ش. شرح الزرقاني على مختصر خليل : الزرقاني ، عبد الباقي ـ الناشر دار الفكر ، بيروت ، لبنان .

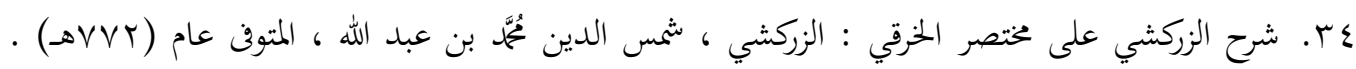

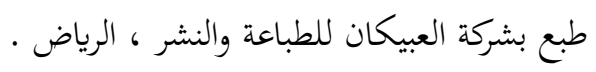

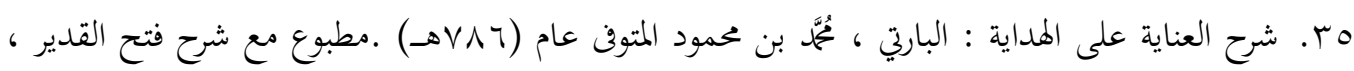

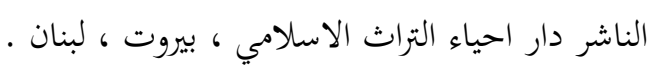

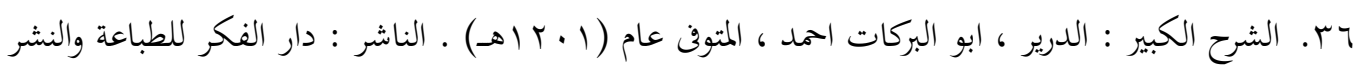
والتوزيع ·

V الع. الشرح الممتع على زاد المستنقع : العثيمين ، تُمَّمَ بن صالح . الناشر : مكتبة اسام ، الرياض ، المملكة العربية السعودية . . السترح

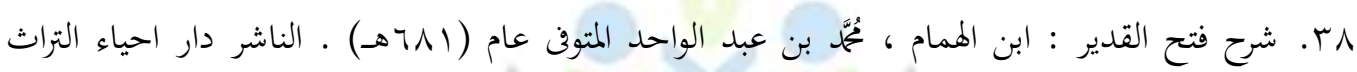

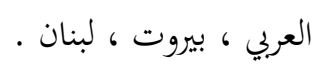

9 ب. شرح منتهى الارادات : البهوتي ، منصور بن يونس المتوفف عام (10 ـ ـ هــ) ـ الناشر دار الفكر.

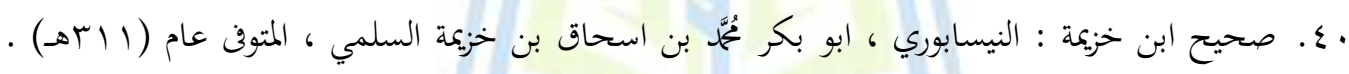

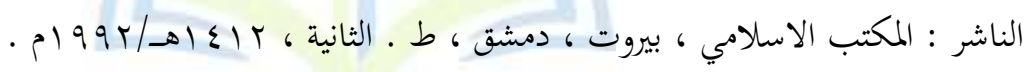

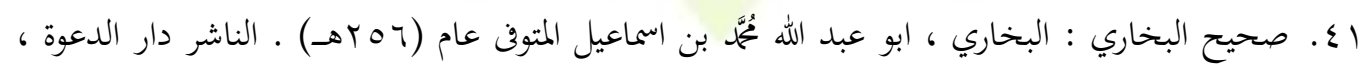
اسطنبول ، تركيا .

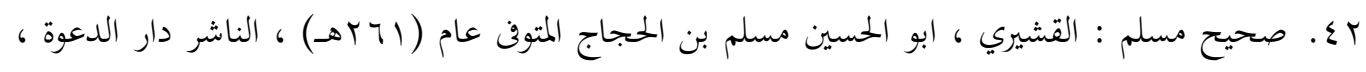
اسطنبول ، تركيا .

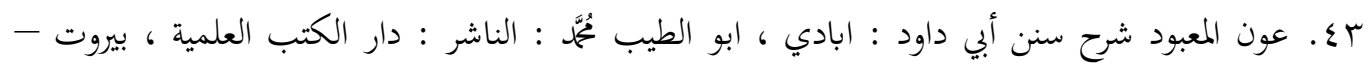

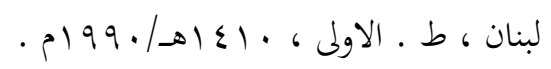

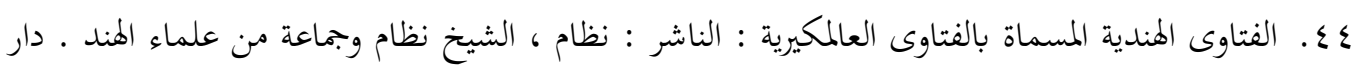

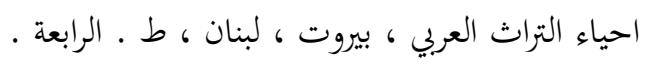

7.

Doi:10.37940/RJIS. 2021.2.1.2 
هـ . فتح المعين : المليباري ، زين الدين بن عبد العزيز . الناشر : دار الفكر ، بيروت.

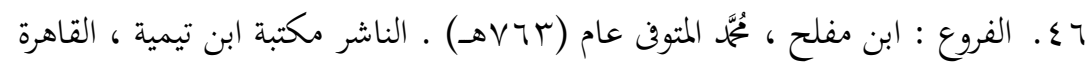

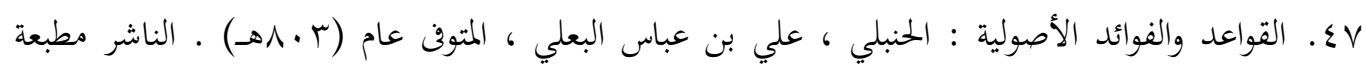

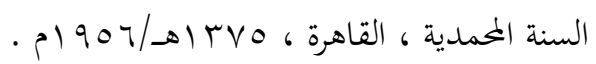

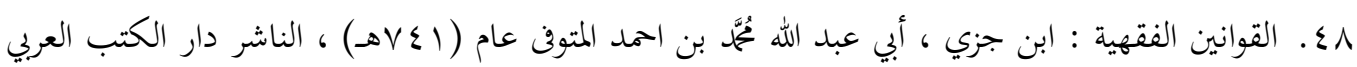

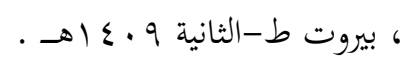

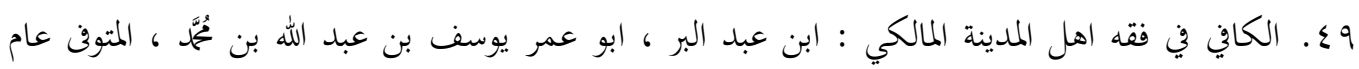

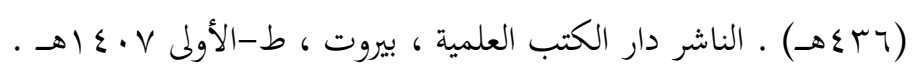

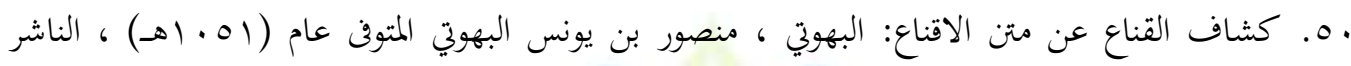

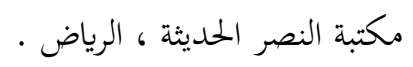

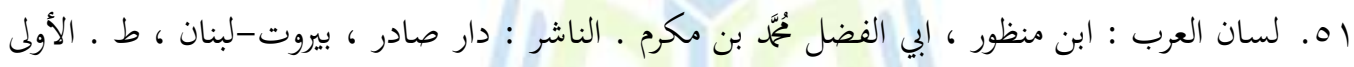
. $199 \cdot|-| 01 \leqslant 1$.

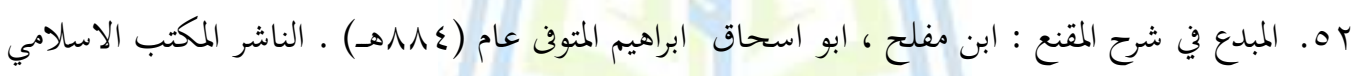

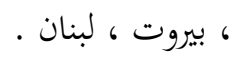

ro ك. مجلة بجمع الفقه الاسلامي ـ الناشر مجمع الفقه الاسلامي بجدة التابع لمنظمة المؤتمر الاسلامي.

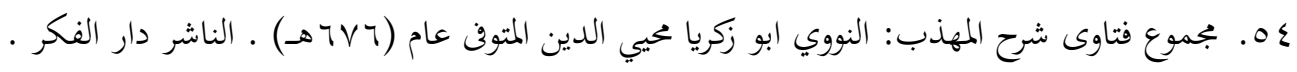

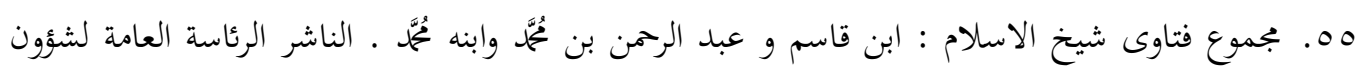

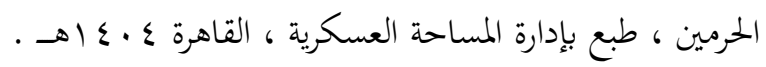

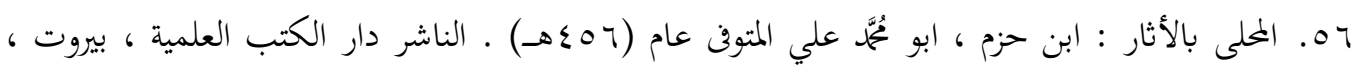
لبنان . n

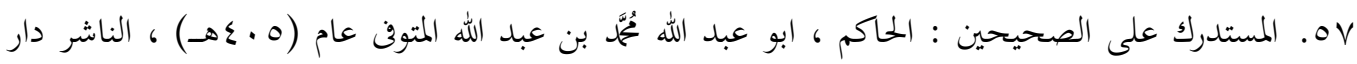

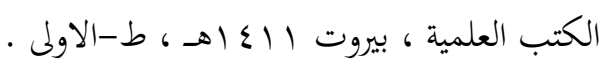


1ه. المسند : ابن حنبل ، الامام احمد المتوفف عام (اء بهـ) ـ الناشر دار الدعوة ، اسطنبول، تركيا.

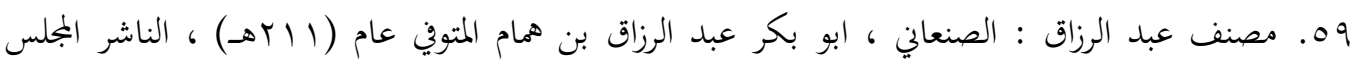

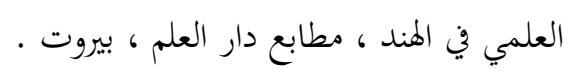

. 7. معجم البلدان : الحموي ،ابو عبد الله ياقوت ـ الناشر : دار احياء التراث العربي ، بيروت - لبنان .

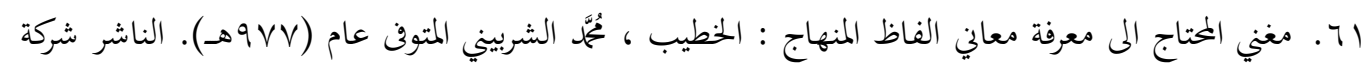

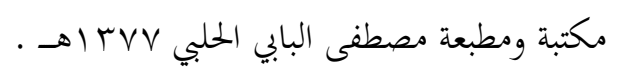

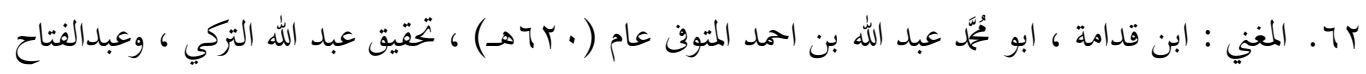

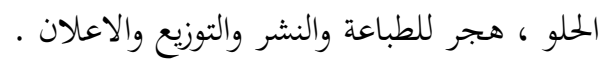

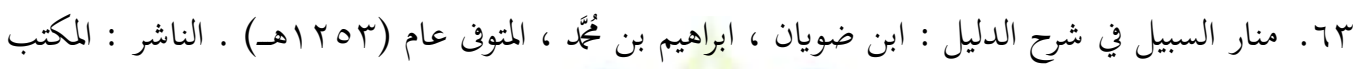

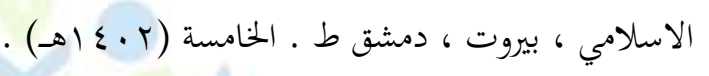

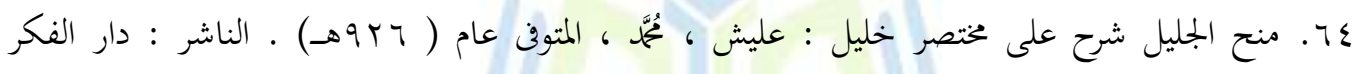

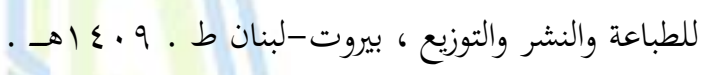

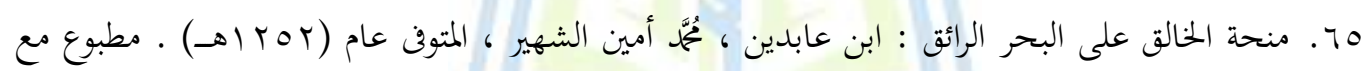

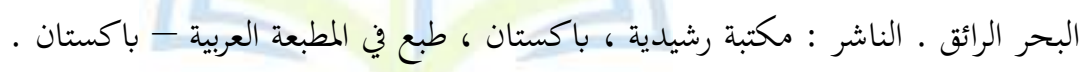

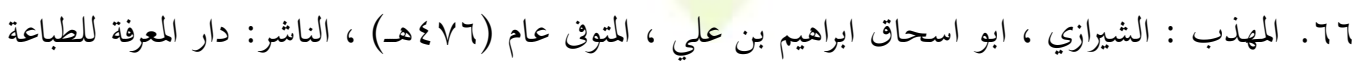

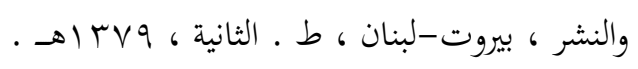

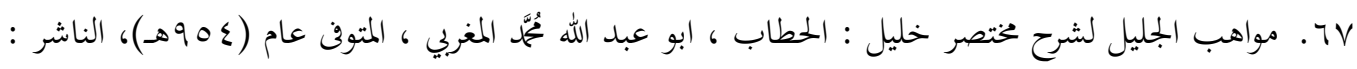

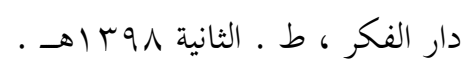

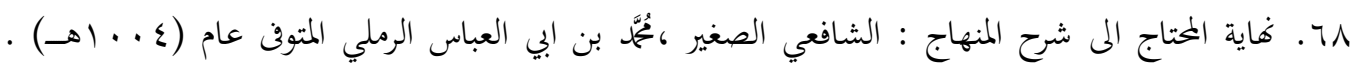

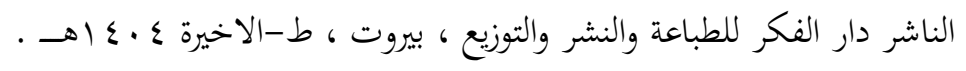

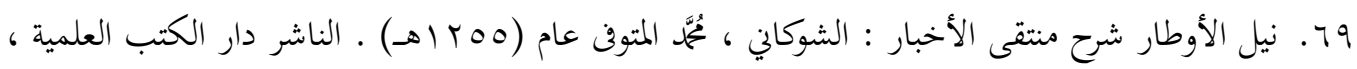

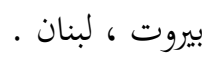




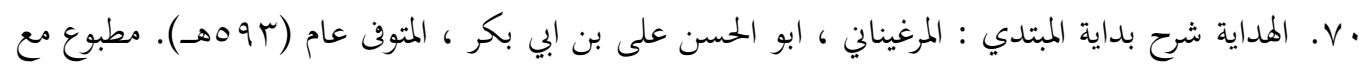

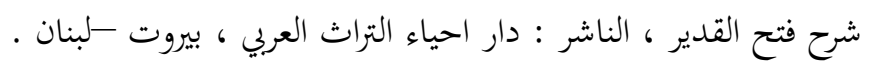

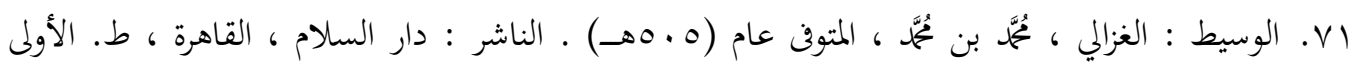

$$
. \rightarrow 1 \vee V
$$

